UIII norden

Kreative erhverv i Norden

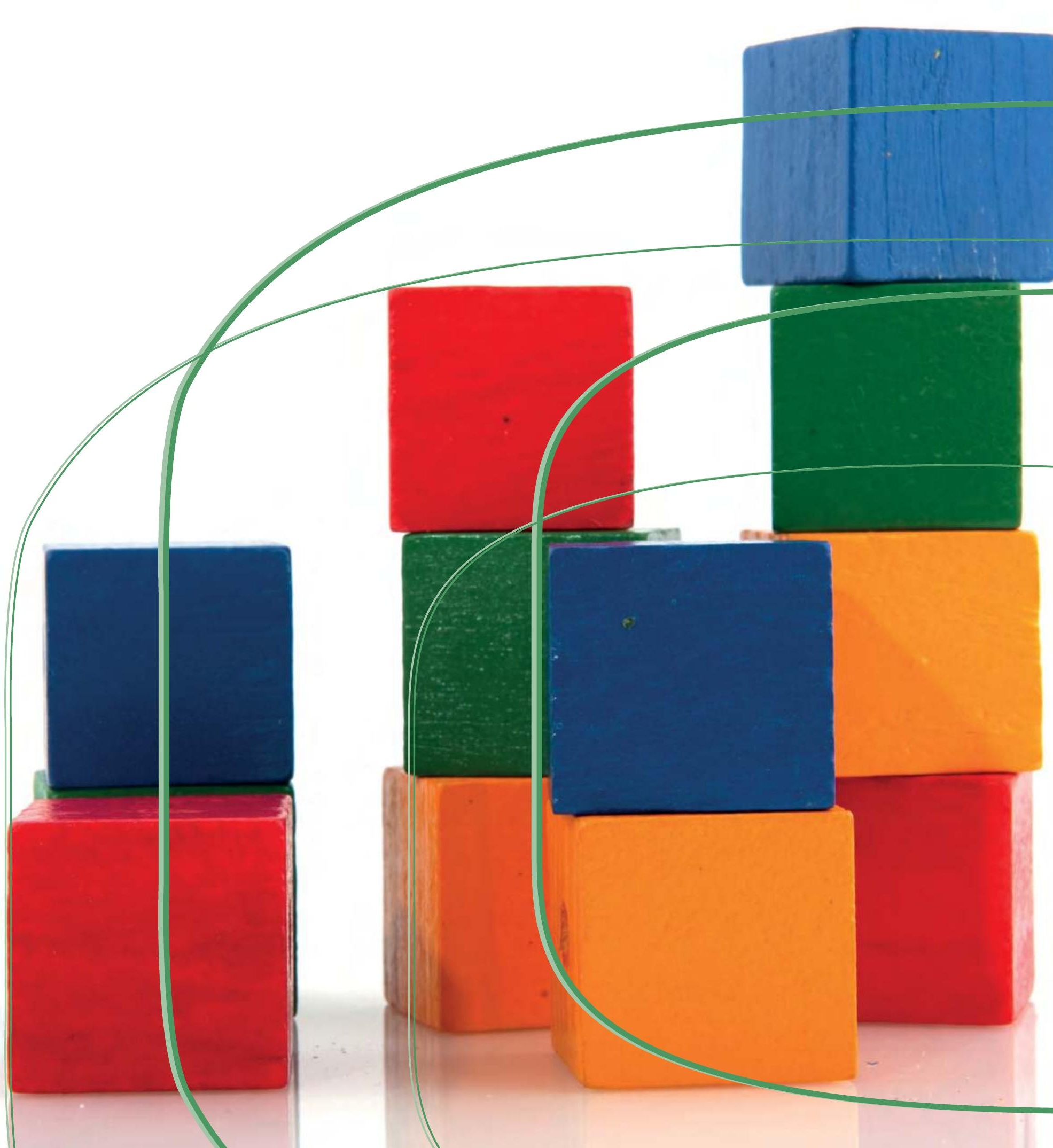







\section{Kreative erhverv i Norden}

Danmarks Statistik

TemaNord 2015:554 
Kreative erhverv i Norden

Danmarks Statistik

ISBN 978-92-893-4255-1 (PRINT)

ISBN 978-92-893-4257-5 (PDF)

ISBN 978-92-893-4256-8 (EPUB)

http://dx.doi.org/10.6027/TN2015-554

TemaNord 2015:554

ISSN 0908-6692

(c) Nordisk Ministerråd 2015

Layout: Hanne Lebech

Omslagsfoto: ImageSelect

Tryk: Rosendahls-Schultz Grafisk

Printed in Denmark

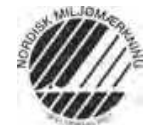

\title{
KRRAINORD
}

\author{
Re
}

Denne rapport er udgivet med finansiel støtte fra Nordisk Ministerråd. Indholdet i rapporten afspejler dog ikke nødvendigvis Nordisk Ministerråds synspunkter, meninger, holdninger eller anbefalinger.

\section{www.norden.org/nordpub}

\section{Det nordiske samarbejde}

Det nordiske samarbejde er en af verdens mest omfattende regionale samarbejdsformer. Samarbejdet omfatter Danmark, Finland, Island, Norge og Sverige samt Færøerne, Grønland og Åland.

Det nordiske samarbejde er både politisk, økonomisk og kulturelt forankret, og er en vigtig medspiller i det europæiske og internationale samarbejde. Det nordiske fællesskab arbejder for et stærkt Norden i et stærkt Europa.

Det nordiske samarbejde ønsker at styrke nordiske og regionale interesser og værdier i en global omverden. Fælles værdier landene imellem er med til at styrke Nordens position som en af verdens mest innovative og konkurrencedygtige regioner.

\section{Nordisk Ministerråd}

Ved Stranden 18

1061 København $\mathrm{K}$

Telefon (+45) 33960200

\section{www.norden.org}




\section{Indhold}

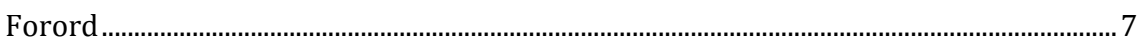

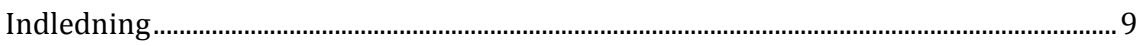

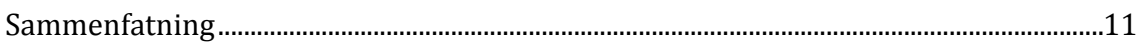

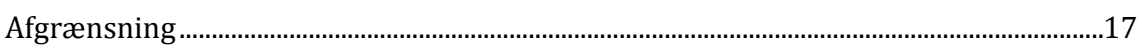

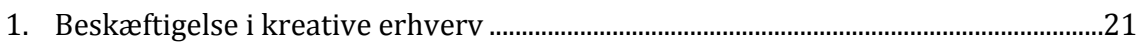

1.1 Gennemsnitlig beskæftigelse i kreative erhverv .............................................26

1.2 Samlet beskæftigelse i kreative erhverv ...............................................................27

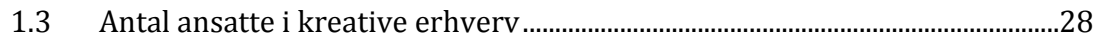

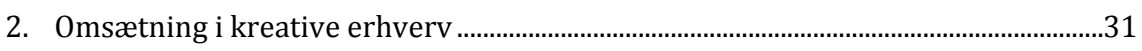

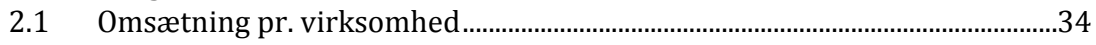

3. Antal virksomheder i kreative erhverv......................................................................

4. Virksomheders størrelse i kreative erhverv.................................................................41

Antal virksomheder fordelt på virksomhedsstørrelser .............................................41

4.1 Beskæftigelse fordelt på virksomhedsstørrelser ...............................................43

4.2 Beskæftigelse pr. virksomhed fordelt på virksomhedsstørrelser...................45

4.3 Omsætning fordelt på virksomhedsstørrelser ..................................................45

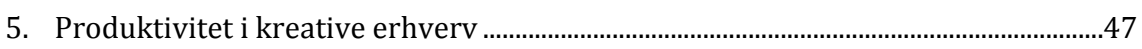

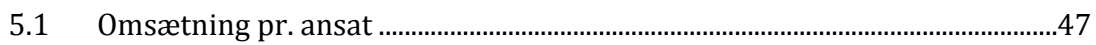

5.2 Omsætning pr. ansat fordelt på virksomhedsstørrelser ..................................49

5.3 Værditilvækst i kreative erhverv .....................................................................50

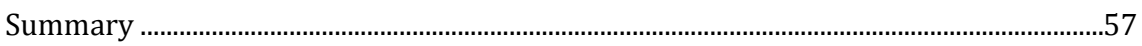

Bilag 1. Anbefalinger til fremtidig belysning af kreative erhverv....................................63

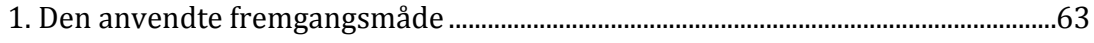

2. Udbygning af den eksisterende statistiske belysning ...............................................64

Analyse af kreativ beskæftigelse.....................................................................................65

Bilag 2. Kreative erhverv og NACE-branchekoder..........................................................67

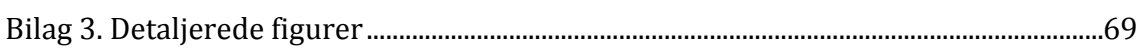





\section{Forord}

Denne rapport er produceret af Danmarks Statistik for KreaNord i 2012, og kortlægger de kreative erhvervs betydning for økonomierne i Danmark, Finland, Norge og Sverige i perioden 2007-2010.

KreaNord blev lanceret i 2008 som en del af Nordisk Ministerråds globaliseringsarbejde, med formålet at udvikle og profilere Norden som ledende inden for kulturelle og kreative erhverv. KreaNord har siden etableret et tværsektorielt policysamarbejde mellem kultur- og erhvervsministerier og myndigheder i de nordiske lande, produceret rapporter og videngrundlag, samt drevet flere projekter om blandt andet entreprenørskab i kunstneriske uddannelser og finansieringsspørgsmål. KreaNord blev afviklet i 2015.

I forbindelse med afviklingen af KreaNord genudgives denne rapport i 2015 sammen med en række andre KreaNord-rapporter. 



\section{Indledning}

De kreative erhverv har de seneste år udgjort en stadig større andel af de nordiske økonomier. Særligt udviklingen af nye teknologier inden for IT og kommunikation driver væksten inden for de kreative erhverv.

Formålet med denne analyse er at kortlægge de kreative erhvervs betydning for økonomierne i Danmark, Finland, Norge og Sverige og derigennem skabe et opdateret videngrundlag for en øget udnyttelse af det erhvervsmæssige potentiale i de kreative erhverv i Norden.

Den deskriptive analyse baserer sig på særudtræk fra eksisterende statistikregistre foretaget af statistikkontorerne i henholdsvis Danmark, Finland, Norge og Sverige. Det har til denne analyse ikke været muligt at indhente data fra Island. Den efterfølgende analyse er gennemført af Danmarks Statistik for Nordisk Ministerråd/KreaNord.

I rapporten vil hvert af de fire landes kreative erhverv blive belyst ud fra erhvervsstatistiske oplysninger. Anbefalinger til udbygning af den statistiske belysning af de kreative erhverv med andre kilder fremgår af bilag 1. Bilag 2 beskriver det detaljerede brancheindhold i de kreative erhverv, mens bilag 3 indeholder udvalgte detaljerede figurer. 



\section{Sammenfatning}

De kreative erhverv i Danmark, Norge og Sverige synes at være mindre påvirket af krisen end det øvrige erhvervsliv i de nordiske lande. De kreative erhvervs andel af det samlede antal beskæftigede er steget med $2 \%$ i Sverige og $10 \%$ i Norge i perioden 2007-2010. Samtidig er beskæftigelsen i øvrige markedsmæssige erhverv faldet med $1 \%$ i Sverige og steget med $7 \%$ i Norge.

Beskæftigelsen i kreative erhverv er faldet med knap $13 \%$ i kreative erhverv i Danmark fra 2007-2010, mens faldet i øvrige erhverv er på 14 \% I Finland er beskæftigelsen i de kreative erhverv faldet med $5 \%$ fra 2007 til 2010, mens beskæftigelsen i øvrige erhverv er faldet med $2 \%$ i samme periode.

Tabel A. Udvikling i årsværk, omsætning, værditilvækst og antal virksomheder. Kreative og øvrige erhverv. 2007-2010

\begin{tabular}{|c|c|c|c|c|}
\hline & Årsværk & Omsætning & Værditilvækst & Antal virksomheder \\
\hline \multicolumn{5}{|l|}{ Danmark } \\
\hline Kreative erhverv & $\div$ & $\div$ & $\div$ & + \\
\hline$\varnothing$ vrige erhverv & $\div$ & $\div$ & $\div$ & $\div$ \\
\hline \multicolumn{5}{|l|}{ Finland } \\
\hline Kreative erhverv & $\div$ & $\div$ & $\ldots$ & + \\
\hline$\varnothing$ vrige erhverv & $\div$ & $\div$ & $\ldots$ & + \\
\hline \multicolumn{5}{|l|}{ Norge } \\
\hline Kreative erhverv & + & + & + & + \\
\hline$\varnothing$ vrige erhverv & + & + & + & + \\
\hline \multicolumn{5}{|l|}{ Sverige } \\
\hline Kreative erhverv & + & + & + & + \\
\hline$\varnothing$ vrige erhverv & $\div$ & + & + & + \\
\hline
\end{tabular}


De kreative erhverv i de fire nordiske lande, Danmark, Finland, Norge og Sverige, beskæftiger i alt lidt over 795.300 årsværk i 2010. Dermed står de kreative erhverv for $13 \%$ af den samlede beskæftigelse i de markedsmæssige erhverv i de fire lande.

De kreative erhverv er af forskellig størrelse i de nordiske lande. I Danmark og Sverige står de kreative erhverv for $15 \%$ af det samlede antal beskæftigede, mens de i Finland dækker over $11 \%$ og i Norge $12 \%$ af beskæftigelsen i 2010.

Figur A. Andel af årsværk i kreative og øvrige erhverv. 2007 og 2010

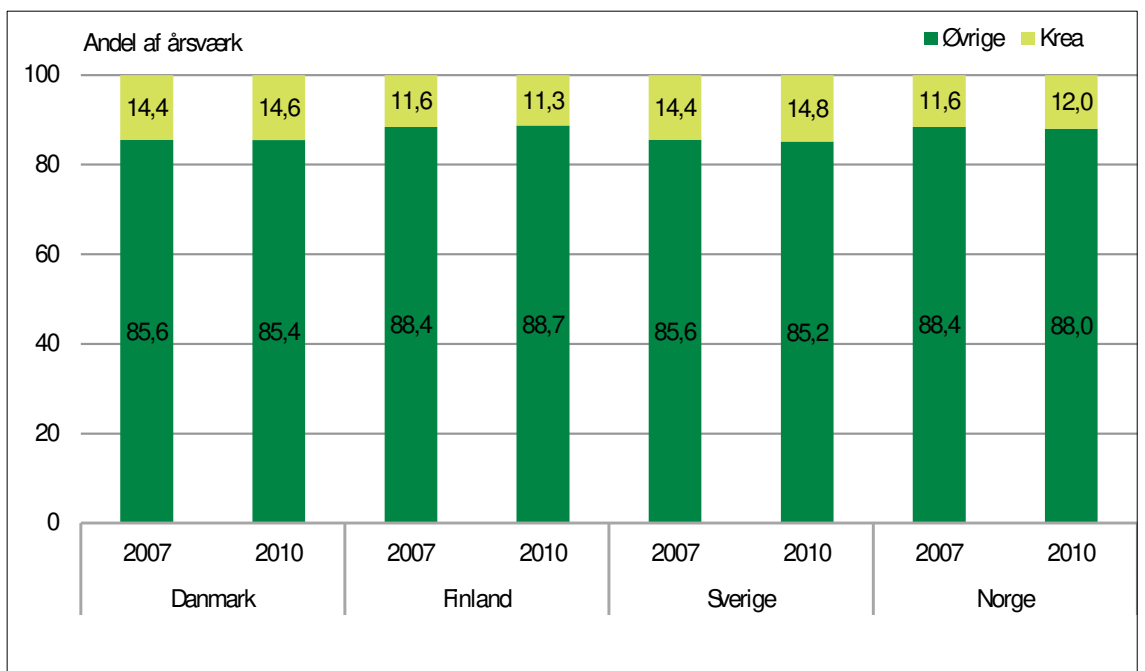

Strukturen i de kreative erhverv er forskellig i de nordiske lande. I Danmark og Norge er Detail den største erhvervsgruppe med $4 \%$ af det samlede antal beskæftigede, mens IT (programmering og services) er den største kreative erhvervsgruppe med 2 hhv. $4 \%$ af den samlede beskæftigelse i markedsmæssige erhverv i Finland og Sverige.

Virksomheder i de kreative erhverv omsatte i Danmark for 360 mia. DKK (13\% af den samlede omsætning i landet svarende til cirka 48 mia. EUR $^{1}$ ), i Finland for 56 mia. EUR (16\% af den samlede omsætning), i Norge for 331 mia. NOK (7 \% af den samlede omsætning, svarende til ca. 40 mia. EUR) og i Sverige for 929 mia. SEK (14 \% af den samlede omsætning, svarende til 108 mia. EUR) i 2010.

1 Den anvendte valutakurs er årets gennemsnit i 2010. Kilde: Danmarks Nationalbank. 
De kreative erhverv i Danmark og Norge har en stabil andel af omsætningen hen over årene 2007-2010. I Finland og Sverige falder andelen af den samlede omsætning i markedsmæssige erhverv. Den særlige udvikling i Finland er forårsaget af udviklingen inden for Telekommunikation, Radio og $T V$, der udgør en betydelig andel af de kreative erhverv i Finland.

Figur B. Andel af omsætning i kreative og øvrige erhverv. 2007 og 2010

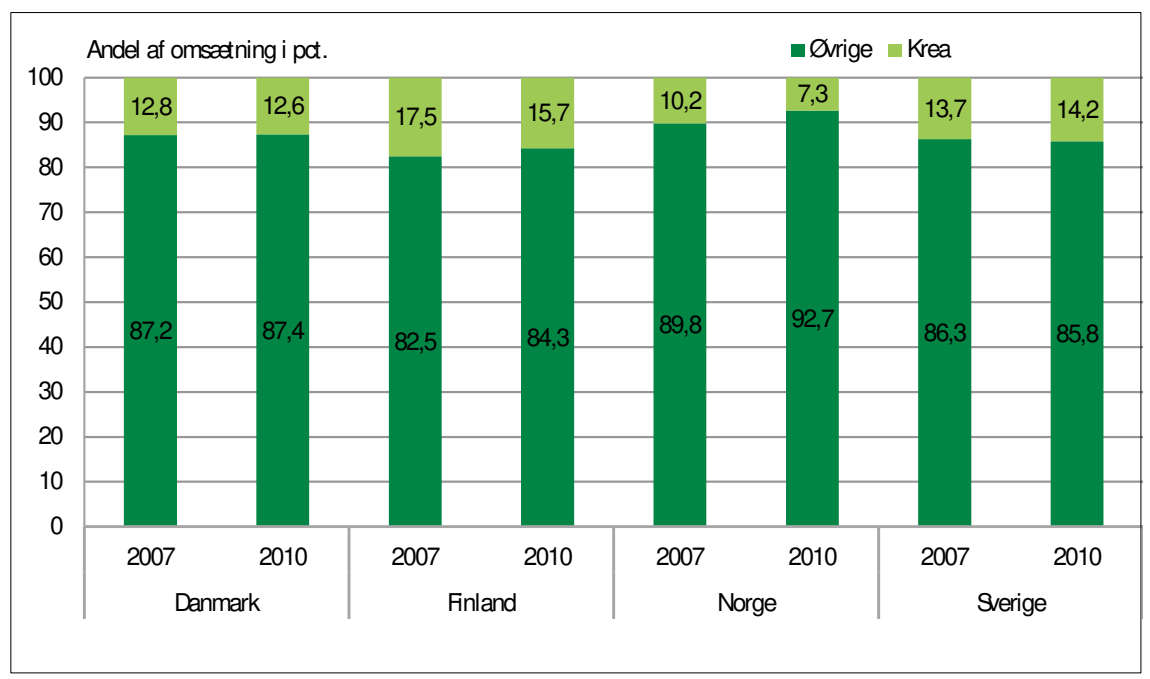

De kreative virksomheder har mindre omsætning pr. ansat end virksomheder i øvrige erhverv i Danmark og Norge. I Sverige og Finland skaber virksomheder i kreative erhverv derimod mere omsætning pr. ansat end virksomheder i øvrige erhverv. Det er særligt IT (hardware og engroshandel), Telekommunikationsudstyr, radio og TV, Film og video og Mode, som skaber mere omsætning pr. ansat end øvrige erhverv.

I 2010 udgør omsætning pr. ansat i kreative erhverv næsten 2,2 mio. DKK i Danmark, mens norske kreative erhverv står for lidt over 2, mio. NOK omsætning pr. ansat. Finske kreative erhverv har en omsætning pr. ansat på 258.000 EUR i 2010. I de kreative erhverv i Sverige genereres lidt over 3.1 mio. SEK i omsætning pr. ansat i samme år.

Det er særligt erhvervsgrupperne Telekommunikationsudstyr, radio og TV, Mode, IT (hardware og engroshandel) samt Film og video, som skaber mere omsætning pr. ansat end andre erhverv. 
I Danmark skaber IT (hardware og engroshandel) og Mode over $60 \%$ mere omsætning pr. ansat end øvrige erhverv i 2010. I Finland genereres over $150 \%$ mere omsætning i IT (hardware og engroshandel) end øvrige erhverv i 2010, mens samme erhvervsgruppe i Sverige skaber over $60 \%$ mere omsætning pr. ansat end øvrige erhverv. Erhvervsgruppen Mode skaber næsten $200 \%$ mere i omsætning pr. ansat end gennemsnittet af øvrige erhverv. I Norge er omsætningen pr. ansat i IT (hardware og engroshandel) $5 \%$ højere end gennemsnittet for øvrige erhverv.

Telekommunikationsudstyr, radio og TV genererer knap $350 \%$ mere omsætning pr. ansat end øvrige erhverv i Finland i 2010, mens det i Sverige skaber næsten $75 \%$ mere omsætning pr. ansat. I Danmark har denne erhvervsgruppe over $15 \%$ højere omsætning end gennemsnittet af øvrige erhverv i 2010.

Film og video, Mode og Telekommunikationsudstyr, radio og TV skaber markant mere værditilvækst pr. ansat end virksomheder i øvrige erhverv. I Danmark skaber Film og video og Mode over 30 \% højere værditilvækst pr. ansat end øvrige erhverv i 2010, mens Mode i Sverige har en værditilvækst pr. ansat, der er over $100 \%$ højere end øvrige erhverv og næsten 30 \% højere i Film og video.

Telekommunikationsudstyr, radio og TV skaber over $50 \%$ højere værditilvækst pr. ansat end øvrige erhverv i Sverige i 2010.

I Danmark og Sverige bliver virksomheder i kreative erhverv mere produktive end virksomheder i øvrige erhverv i perioden 2007-2010. Værditilvækst pr. ansat stiger i perioden med $20 \%$ blandt kreative erhverv mod kun $10 \%$ i øvrige erhverv i Danmark, mens den tilsvarende udvikling for virksomheder i svenske kreative erhverv er $12 \%$, hvor værditilvækst pr. ansat i øvrige erhverv stiger med $6 \%$ i samme periode. I Norge er værditilvækst pr. ansat steget med $9 \%$ i kreative erhverv i perioden fra 2007-2010, mens stigningen i øvrige erhverv er på 67 \% i samme periode. ${ }^{2}$

2 Oplysninger om værditilvækst foreligger ikke for Finland. 
Figur C. Udviklingen i værditilvækst pr. ansat i kreative erhverv. 2007-2010

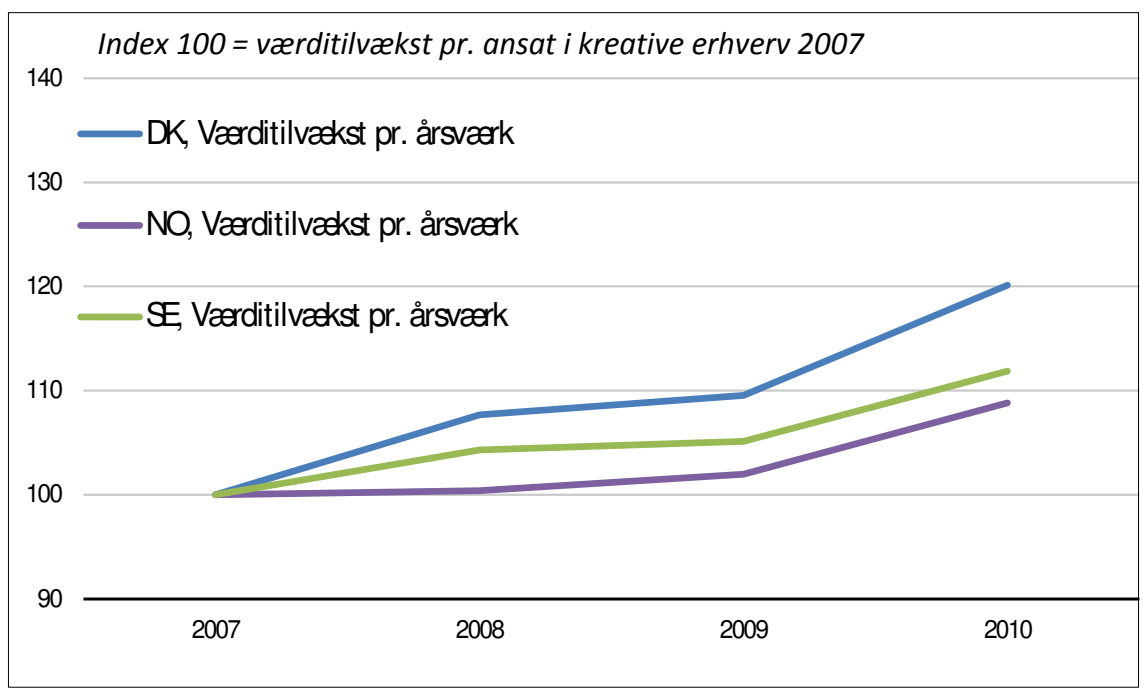

Antallet af virksomheder i kreative erhverv i Norden har været relativt stabil i perioden 2007-2010. Andelen af kreative virksomheder er højest i Sverige med over $25 \%$ af alle aktive virksomheder (næsten 170.000) og lavest i Finland med knap 11 \% (33.000).

Figur D. Andel af kreative og øvrige virksomheder. 2007 og 2010

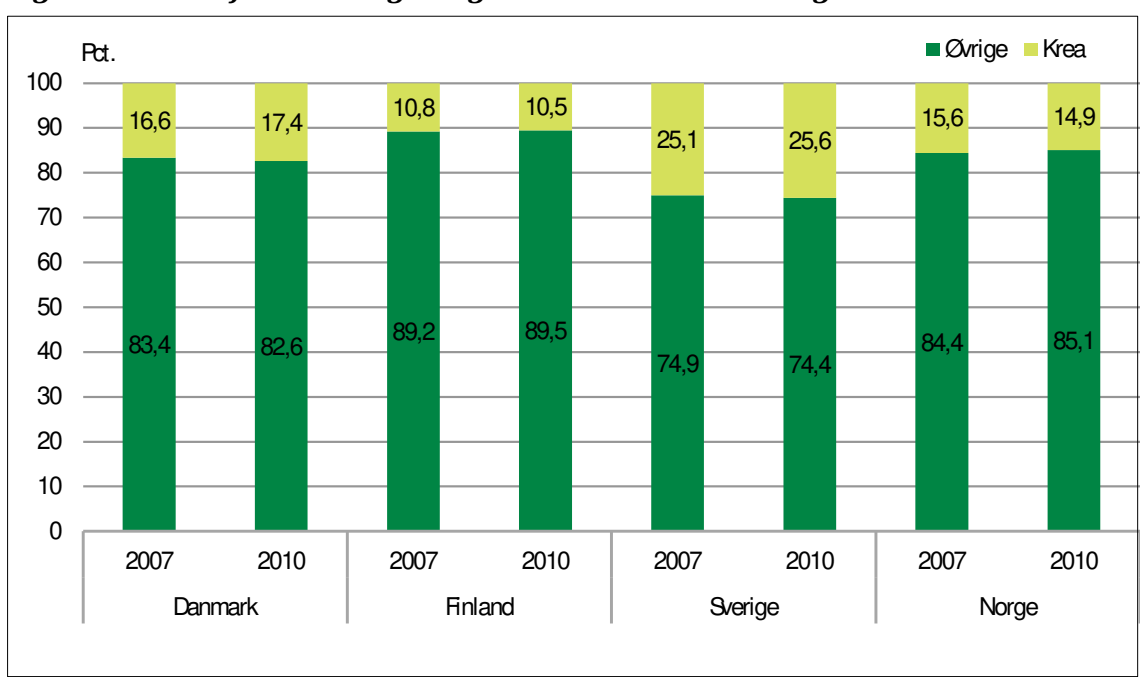

Det kreative erhverv med størst andel af virksomheder i perioden 2007-2010 var Detail i Danmark (ca. 5 \%), Norge (ca. 4 \%). og Finland (ca. $3 \%$ ). I Sverige er det største kreative erhverv IT (programmering 
og services), som udgør over $5 \%$ af alle aktive virksomheder i markedsmæssige erhverv i årene 2007-2010.

IT (programmering og services) er det næststørste kreative erhverv i Danmark i årene 2007-2010 med omkring $3 \%$ af landets virksomheder. Det samme gør sig gældende i Norge i 2007-2010 (ligeledes ca. $3 \%$ ).

I Finland er Bøger og presse og IT (programmering og services) lige store og udgør 1,4\% af landets virksomheder og er dermed de næststørste kreative erhverv i 2007 og 2008, men antallet af virksomheder i Bøger og presse falder i 2009, mens IT (programmering og services) vokser og bliver det næststørste kreative erhverv i 2009. I 2010 udgør IT (programmering og services) 1,5 \% af virksomhederne i Finland.

Størstedelen af omsætningen i de kreative erhverv genereres af de relativt få store virksomheder med mindst 100 årsværk ansat. I Finland står virksomhederne i denne størrelsesgruppe for $71 \%$ af den samlede omsætning i kreative erhverv i 2010, mens andelen i de andre tre lande ligger på omkring $40 \%$

Samtidig har de mindste virksomheder i kreative erhverv flere beskæftigede end virksomheder af samme størrelse i øvrige erhverv i Danmark, Norge og Sverige. Modsat er det i Finland, hvor store virksomheder i kreative erhverv beskæftiger flere end tilsvarende virksomheder i øvrige erhverv. 


\section{Afgrænsning}

Analysen inddrager oplysninger om erhvervslivet og de kreative erhverv i perioden 2007-2010. Danmark, Finland, Norge og Sverige sammenlignes i den deskriptive analyse med udgangspunkt i oplysninger om antallet af aktive virksomheder, beskæftigelse, omsætning og værditilvækst i de kreative erhverv og ørige ikke-finansielle markedsmæssige erhverv.

I denne rapport defineres de kreative erhverv ud fra en bred definition, som inkluderer fremstillings-, engroshandels- og detailhandelsvirksomheder. Definitionen af kreative erhverv bygger på en værdikædebetragtning fra fremstilling over handel til rådgivning.

Engros- og detailhandel er medtaget, idet en række kreative virksomheder, der producerer og sælger kreative produkter, er registreret som engrosvirksomhed. Samtidig videresælges mange "kreative" produkter i detailhandlen. ${ }^{3}$ Detailbranchen er i nærværende analyse afgrænset til at indeholde de delbrancher, som antages hovedsageligt at handle med "kreative" produkter. Denne erhvervsgruppe adskiller sig dog i denne rapport fra de andre 12 erhvervsgrupper, idet Detail defineres som en tværgående kreativ erhvervsgruppe, der knytter sig til flere af de andre kreative industrier.

De kreative erhverv kan overordnet grupperes i kategorierne produktion og handel, videnservice og indhold. De nationale statistikker belyser produktion- og handelsvirksomhederne meget detaljeret, mens oplysningerne om videnservice og indhold er mere begrænsede.

Afgrænsningen af de kreative erhverv baseres på den internationale branchenomenklatur, NACE, rev. $2 .{ }^{4}$ Branchekoderne inddeles i 13 kreative erhvervsgrupper; Arkitektur, Bøger og presse, Design, Detail, Film og video, IT (hardware og engroshandel), Musik, IT (programmering og ser-

\footnotetext{
${ }^{3}$ Detailhandelsbranchen kan dække over aktiviteter forbundet med andre produkter end produkter, der kan knyttes til en kreativ branche; derfor forsøges detailbranchen så vidt muligt at blive analyseret særskilt i denne rapport.

${ }^{4}$ NACE er en fælles branchenomenklatur i EU. NACE rev. 2 gælder fra 1. januar 2008 i alle EU medlemslande ifølge forordning 1893/2006.
} 
vices), Kunst og kunsthåndværk, ${ }^{5}$ Mode, Møbler og interiør, Telekommunikationsudstyr, radio og TV samt Reklame.

Hver kreativ erhvervsgruppe består af en eller flere 4-cifrede branchekoder jf. Bilag 2. Nedenfor præsenteres de 13 kreative erhvervsgrupper og deres overordnede indhold i alfabetisk orden.

\section{Arkitektur}

Omfatter arkitektrådgivning, bygningstegning og projekteringsarbejde samt byplanlægning og landskabsarkitektur.

\section{Bøger og presse}

Dækker bogbinding og lignende serviceydelser, nyheds- og pressebureauer, trykning af aviser og magasiner, udgivelse af aviser og magasiner, engroshandel med bøger, papir og papirvarer samt fotografisk virksomhed.

3. Design

Omfatter specialiseret designarbejde såsom industriel design og produktdesign, kommunikations- og grafisk design samt indretningsarkitekter og rumdesign.

\section{Detail}

Omfatter biografer, specialforretninger såsom kunsthandlere, forhandlere af brugskunst, detailhandel med ure og smykker, sko og lædervarer, tøjforretninger, detailhandel med musik og video samt aviser og bøger. Desuden indgår møbel- og boligindretningsforretninger, forhandlere af radio-, tv- og computerudstyr samt udlejning af video.

\section{Film og Video}

Dækker produktion af spillefilm og andre film, også digital distribution til fremvisning i biografer eller på tv. Herunder indgår også filmredigering, distribution af film samt køb og salg af distributionsrettigheder.

\section{IT (hardware og engroshandel)}

Omfatter udgivelse af computerspil, fremstilling af computere og tilbeh $\emptyset$ r til computere samt engroshandel med computere, software og tilbehør hertil.

\section{IT (programmering og services)}

Omfatter computerprogrammering og konsulentbistand knyttet til informationsteknologi samt udgivelse af anden software.

\section{Kunst og kunsthåndværk}

Indbefatter aktiviteter, som knytter sig til offentlighedens interesser inden for kultur, forlystelser og sport såsom levende optræden, museer, spillevirksomhed, sport og fritidsaktiviteter.

\section{Mode}

Dækker fremstilling af forskellige former for $t ø j$ - og tilbeh $\varnothing \mathrm{r}$ såsom halst $\varnothing$ rklæder, tasker og kufferter samt fremstilling af sko, ure, smykker. I erhvervet indgår også agenturhandel med de nævnte varegrupper og engroshandel med tøj og sko samt ure og smykker.

\section{Musik}

Omfatter fremstilling af musikinstrumenter, metronomer, stemmegafler og lignende, indspilning og udgivelse af lydoptagelser og musik samt reproduktion af indspillede medier.

${ }^{5}$ Brancherne i det kreative erhverv Kunst og håndværk opgøres ikke i norsk strukturel erhvervsstatistik og er dermed ikke med i denne rapport. 


\section{Møbler og interiør}

Indbefatter fremstilling af gulvtæpper og måtter, møbler og overfladebehandling til møbler og fremstilling af tekstilvarer som ikke er boligtekstiler; såsom flag, presenninger, telte og markiser. Desuden indgår fremstilling af keramiske husholdningsartikler såsom bordservice, toiletartikler og pyntegenstande samt fremstilling af lamper, elektriske pærer og tilbehør hertil. Dækker også agenturhandel med møbler, husholdningsartikler og isenkram og engroshandel med porcelæns- og glasvarer samt møbler, tæpper og belysning.

\section{Reklame}

Omfatter reklamebureauer, markedsføring af varer, rådgivning knyttet til reklamevirksomhed, dekoratører, opsætning af reklamer og lignende.

12. Telekommunikationsudstyr, radio og TV

Dækker fremstilling af kommunikationsudstyr såsom mobiltelefoner, udstyr til kabel-tv, og trådløse telefoner samt engroshandel med elektriske husholdningsartikler såsom hårde hvidevarer, radio- og tv-udstyr, fotografisk udstyr, og elektriske husholdningsartikler. Denne gruppe omfatter endvidere produktion af radio-, tv- og dataprogrammer.

I denne rapport er fokus lagt hovedsageligt på sammenligningen mellem de kreative erhverv og øvrige markedsmæssige erhverv samt til dels de separate 13 kreative erhverv. Der fokuseres ikke på de 4-cifrede underliggende NACE-brancher, idet disse brancher i mange tilfælde består af få virksomheder, hvilket ville gøre analysens resultater statistisk mindre robuste. 



\section{Beskæftigelse i kreative erhverv}

I denne analyse anvendes årsværk for ansatte som indikator for beskæftigelsen; selv-stændige erhvervsdrivende indgår således ikke i det samlede beskæftigelsesmål, da data for selvstændigt erhvervsdrivende ikke er til rådighed for alle lande.

Beskæftigelsen i de kreative erhverv udgør omkring 170.000 årsværk i Danmark, 160.000 i Finland, næsten 330.000 årsværk i Sverige og over 134.000 årsværk i Norge i 2010 jf. tabel 1.

Tabel 1. Beskæftigelse i kreative og øvrige virksomheder, 2007-2010

\begin{tabular}{|c|c|c|c|c|c|c|c|}
\hline & \multicolumn{4}{|c|}{ Årsværk (Antal) } & \multicolumn{3}{|c|}{ Årlig ændring (\%) } \\
\hline & 2007 & 2008 & 2009 & 2010 & 2007-2008 & 2008-2009 & 2009-2010 \\
\hline \multicolumn{8}{|c|}{ Alle erhverv } \\
\hline Danmark & 1.355 .946 & 1.376 .416 & 1.221 .343 & 1.169 .824 & 1,5 & $-12,7$ & $-4,4$ \\
\hline Finland & 1.481 .868 & 1.502 .213 & 1.447 .403 & 1.444 .031 & 1,4 & $-3,8$ & $-0,2$ \\
\hline Sverige & 2.220 .829 & 2.278 .566 & 2.190 .788 & 2.209 .162 & 2,5 & $-4,0$ & 0,8 \\
\hline Norge & 1.049 .415 & 1.189 .173 & 1.144 .152 & 1.122 .393 & 11,8 & $-3,9$ & $-1,9$ \\
\hline \multicolumn{8}{|c|}{ Kreative erhverv } \\
\hline Danmark & 195.392 & 194.798 & 177.857 & 170.300 & $-0,3$ & $-9,5$ & $-4,4$ \\
\hline Finland & 171.677 & 175.492 & 168.900 & 163.020 & 2,2 & $-3,9$ & $-3,6$ \\
\hline Sverige & 320.607 & 334.777 & 327.916 & 327.817 & 4,2 & $-2,1$ & 0,0 \\
\hline Norge & 121.766 & 139.884 & 133.703 & 134.178 & 13,0 & $-4,6$ & 0,4 \\
\hline \multicolumn{8}{|c|}{$\emptyset$ vrige erhverv } \\
\hline Danmark & 1.160 .554 & 1.181 .618 & 1.043 .486 & 999.524 & 1,8 & $-13,2$ & $-4,4$ \\
\hline Finland & 1.310 .193 & 1.326 .722 & 1.278 .512 & 1.281 .009 & 1,2 & $-3,8$ & 0,2 \\
\hline Sverige & 1.900 .222 & 1.943 .789 & 1.862 .872 & 1.881 .345 & 2,2 & $-4,3$ & 1,0 \\
\hline Norge & 927.651 & 1.049 .295 & 1.010 .447 & 988.214 & 11,6 & $-3,8$ & $-2,2$ \\
\hline
\end{tabular}

I 2010 ligger de kreative erhvervs andel af beskæftigelsen omregnet til årsværk på $15 \%$ af den samlede beskæftigelse i markedsmæssige erhverv i Danmark og Sverige, mens de i Finland udgør $11 \%$ De norske kreative erhvervs andel af den samlede beskæftigelse ligger på $12 \%$ samme år. 
Figur 1. Andel af årsværk i kreative erhverv og øvrige erhverv. 2007 og 2010

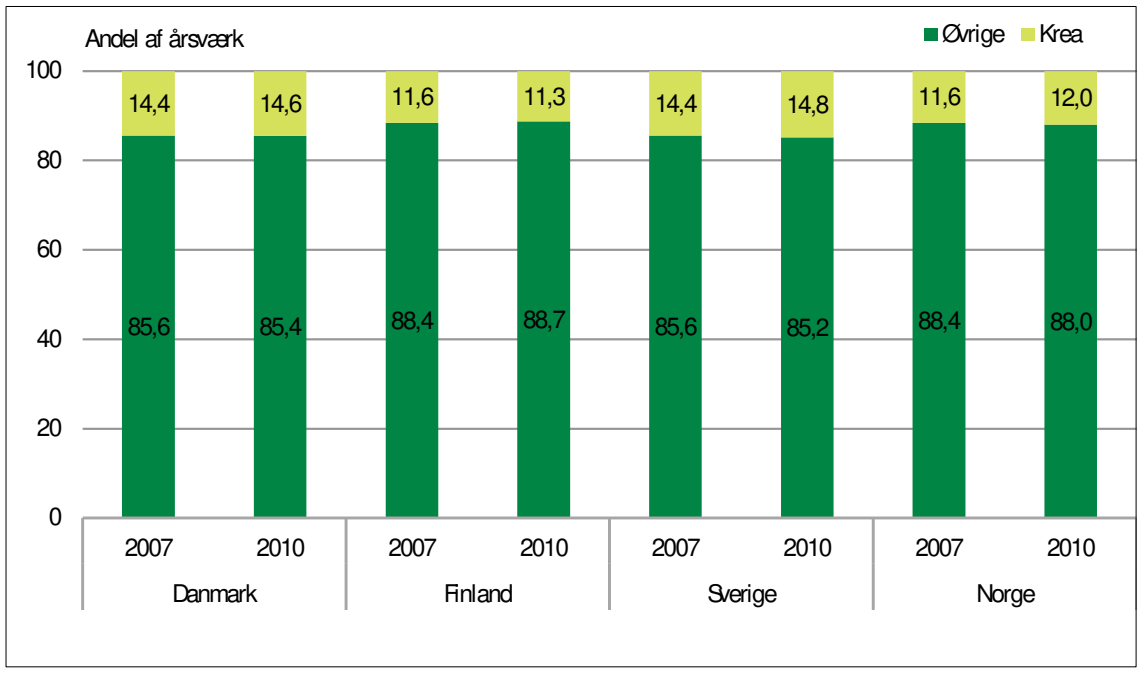

I samtlige lande ændres andelene minimalt fra 2007 til 2010; i de danske kreative erhverv er beskæftigelsen steget med i alt 0,2 \% i perioden, mens stigningen i Sverige og Norge ligger på 0,4\% De finske kreative erhverv har oplevet et fald i deres andel af beskæftigelsen svarende til $0,3 \%$ i løbet af samme periode.

Størstedelen af beskæftigelsen i kreative erhverv ligger i Danmark og Norge i Detail (knap $4 \%$ af den samlede beskæftigelse i markedsmæssige erhverv) i alle årene 2007-2010, mens det samme gør sig gældende for Sverige i 2007, hvorefter IT (programmering og services) står for størstedelen af beskæftigelsen med 3,7 \% i 2008 og 3,9 \% i henholdsvis 2009 og 2010.

Figur 2a. Antal årsværk i kreative erhverv. Danmark 2010

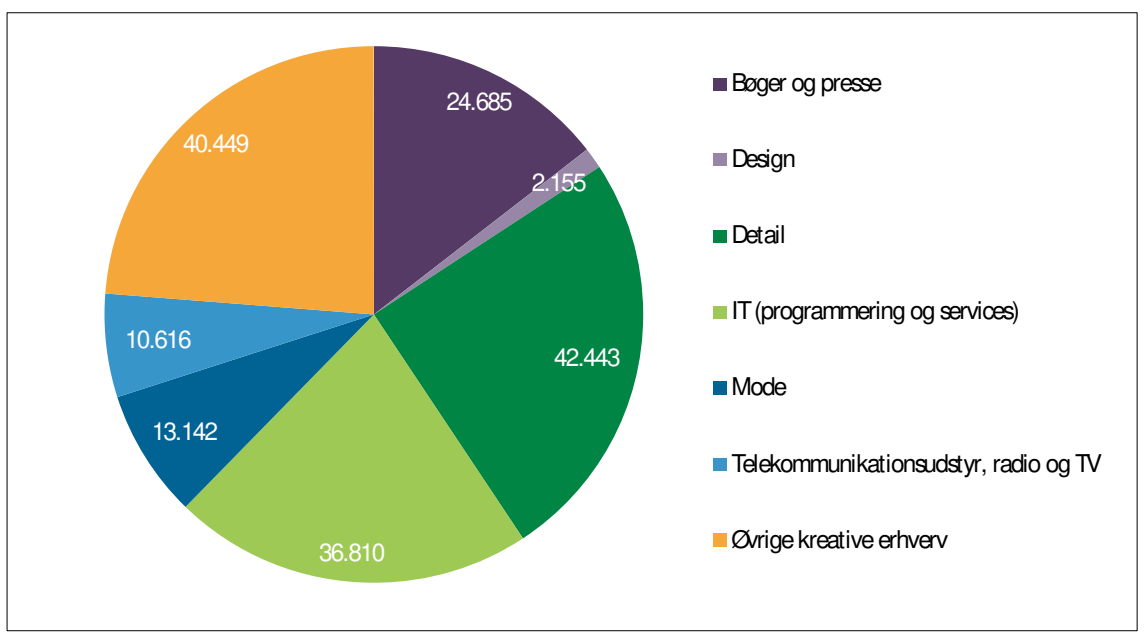


I Danmark er over 42.000 årsværk ansat i Detail i 2010, mens IT (programmering og services) dækker over næsten 37.000 årsværk i samme år.

I Finland er Telekommunikationsudstyr, radio og TV det største kreative erhverv med en beskæftigelsesandel på omkring 2,3 \% i 2007 og 2008 - stærkt efterfulgt af IT (programmering og services), som står for størstedelen af beskæftigelsen i de efterfølgende år med 2,3 \% af den samlede beskæftigelse i markedsmæssige erhverv.

Det er særligt underbranchen "Fremstilling af kommunikationsudstyr", der dækker over en stor andel af beskæftigelsen i Telekommunikationsudstyr, radio og TV i Finland.

\section{Figur 2b. Antal årsværk i kreative erhverv. Finland 2010}

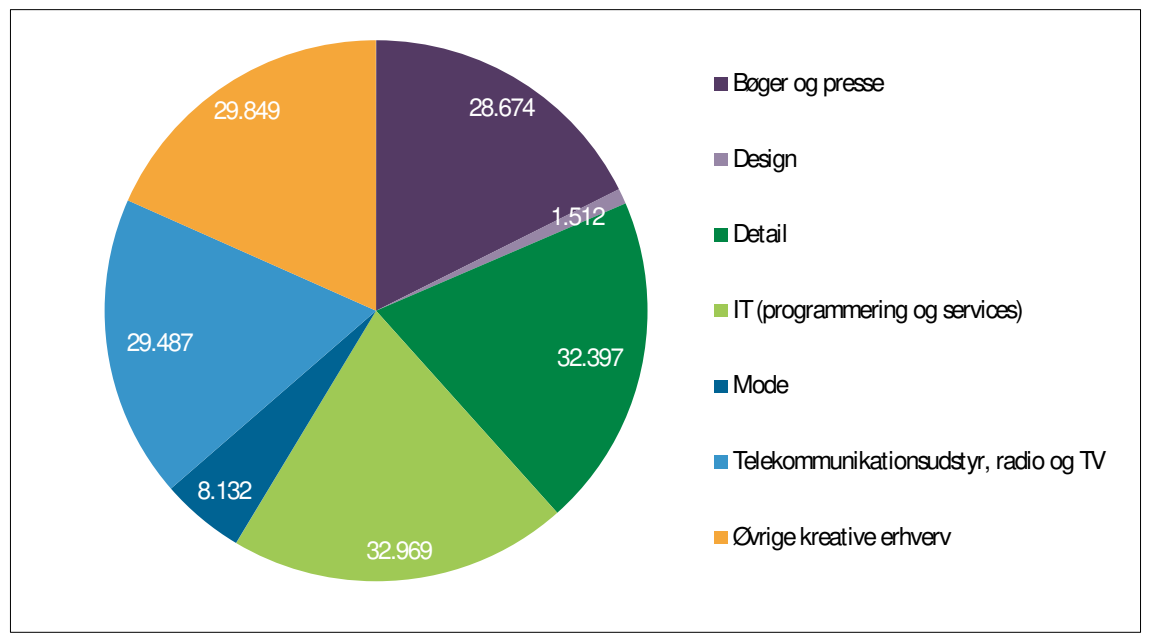

Telekommunikationsudstyr, radio og TV dækker samtidig over mellem 20 og $18 \%$ af beskæftigelsen i de kreative erhverv i Finland i perioden 2007-2010, mens IT (programmering og services) står for mellem 17-20\% af beskæftigelsen blandt de kreative erhverv i samme periode.

I 2010 er der knap 33.000 årsværk beskæftiget i IT (programmering og services) i Finland, mens Telekommunikationsudstyr, radio og TV står for næsten 29.500 årsværk i samme år.

Musik står for den mindste andel af landenes samlede beskæftigelse blandt de kreative erhverv. Fra 2007-2010 er kun 0,02-0,08 \% af landenes samlede beskæftigelse placeret i denne branche i Danmark (0,05 \% i 2010), Finland (0,05 \%), Sverige og Norge (henholdsvis 0,07 \% og 0,02 \% i 2010).

I Finland er det endvidere Kunst og kunsthåndværk og Design, som står for under 0,02 \% af landets samlede beskæftigelse. 
Figur 2c. Antal årsværk i kreative erhverv. Norge 2010

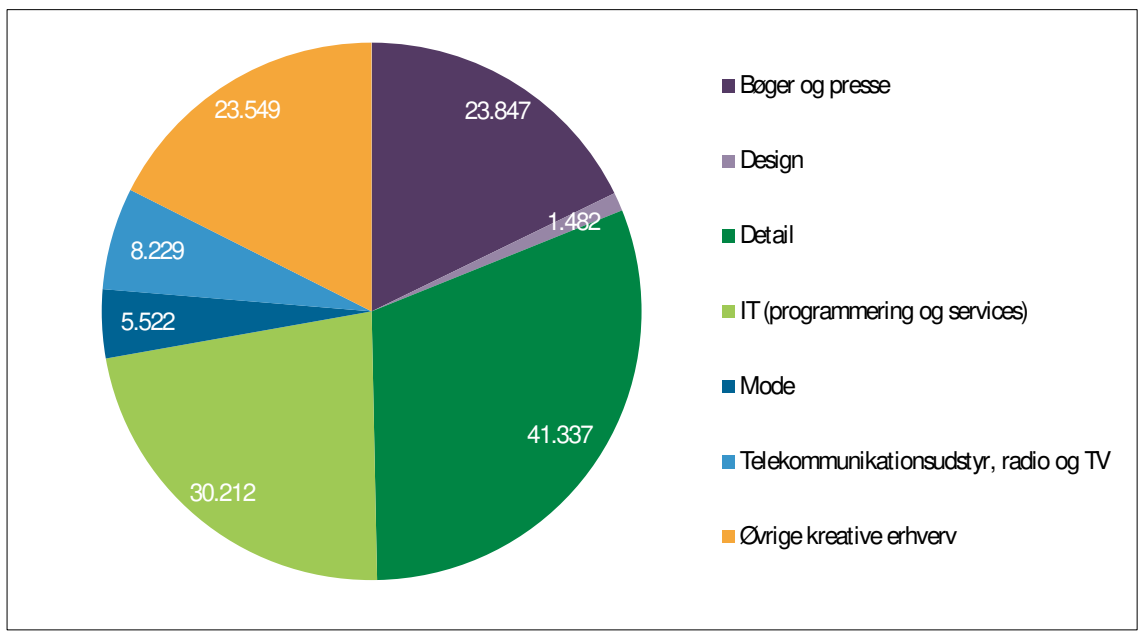

I Norge er Film og videoproduktion samt Design de kreative erhverv med mindste beskæftigelsesandel svarende til 0,1 \% af den samlede beskæftigelse i markedsmæssige erhverv i 2010.

I 2010 har Detailerhvervet mere end 41.000 årsværk i Norge, mens IT (programmering og services) har over 30.000 årsværk i samme år.

Figur 2d. Antal årsværk i kreative erhverv. Sverige 2010

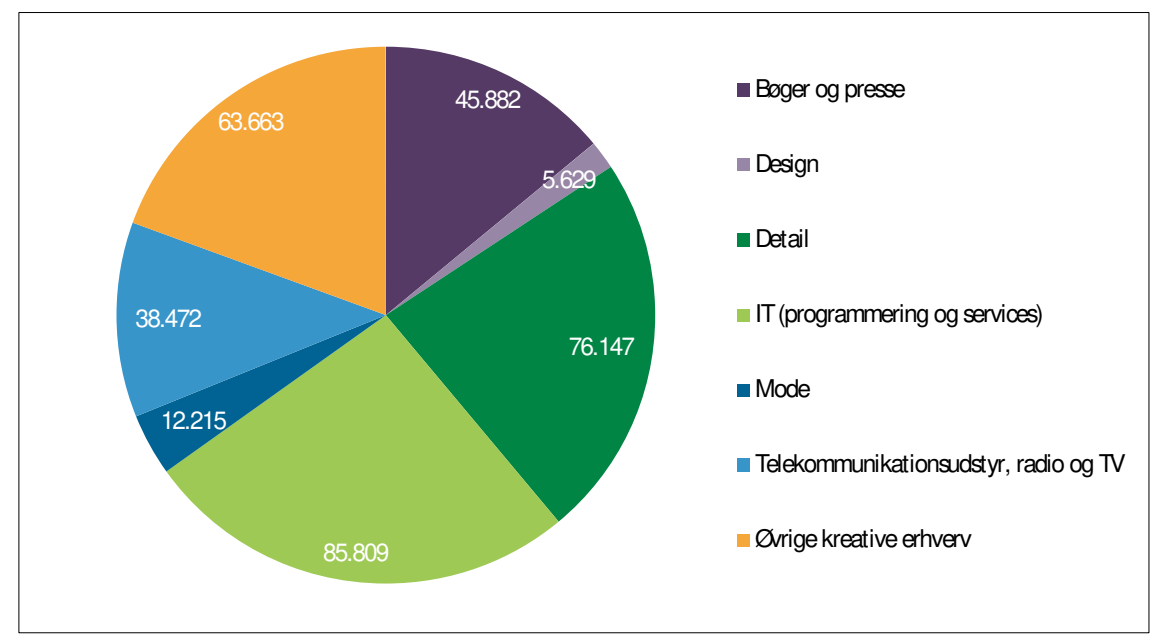

I Sverige står IT (programmering og services) for næsten 86.000 årsværk i 2010, mens Detail har over 76.000 årsværk i samme år. 
Tabel 2. Årsværk i kreative erhverv. 2007-2010

\begin{tabular}{|c|c|c|c|c|}
\hline & & Årsværk & & \\
\hline & 2007 & 2008 & 2009 & 2010 \\
\hline Kreative e & & & & \\
\hline Danmark & 195.392 & 194.798 & 177.857 & 170.300 \\
\hline Finland & 171.677 & 175.492 & 168.900 & 163.020 \\
\hline Sverige & 320.607 & 334.777 & 327.916 & 327.817 \\
\hline Norge & 121.766 & 139.884 & 133.703 & 134.178 \\
\hline Heraf:Ark & & & & \\
\hline Danmark & 6.598 & 6.644 & 5.393 & 5.055 \\
\hline Finland & 4.060 & 4.050 & 3.704 & 3.748 \\
\hline Sverige & 5.670 & 5.912 & 6.002 & 5.968 \\
\hline Norge & 3.926 & 4.278 & 4.019 & 4.049 \\
\hline Bøger og & & & & \\
\hline Danmark & 30.780 & 29.610 & 26.704 & 24.685 \\
\hline Finland & 32.122 & 31.397 & 29.664 & 28.674 \\
\hline Sverige & 49.630 & 49.860 & 46.777 & 45.882 \\
\hline Norge & 14.119 & 27.288 & 24.856 & 23.847 \\
\hline Design & & & & \\
\hline Danmark & 2.187 & 2.393 & 2.193 & 2.155 \\
\hline Finland & 1.339 & 1.556 & 1.521 & 1.512 \\
\hline Sverige & 5.166 & 5.591 & 5.406 & 5.629 \\
\hline Norge & 1.269 & 1.494 & 1.386 & 1.482 \\
\hline Detail & & & & \\
\hline Danmark & 45.515 & 46.748 & 43.157 & 42.443 \\
\hline Finland & 32.649 & 33.510 & 33.292 & 32.397 \\
\hline Sverige & 75.405 & 74.787 & 75.587 & 76.147 \\
\hline Norge & 40.021 & 41.934 & 40.741 & 41.337 \\
\hline Film og vic & & & & \\
\hline Danmark & 2.988 & 3.035 & 2.918 & 2.863 \\
\hline Finland & 2.283 & 2.372 & 2.268 & 2.275 \\
\hline Sverige & 5.403 & 5.243 & 5.348 & 5.424 \\
\hline Norge & 1.257 & 1.275 & 1.390 & 1.393 \\
\hline IT (hardw & & & & \\
\hline Danmark & 10.700 & 10.448 & 9.654 & 9.041 \\
\hline Finland & 5.469 & 5.383 & 5.393 & 5.013 \\
\hline Sverige & 15.334 & 15.355 & 14.008 & 13.431 \\
\hline Norge & 7.261 & 7.178 & 6.977 & 6.810 \\
\hline IT (progra & & & & \\
\hline Danmark & 34.195 & 35.833 & 36.968 & 36.810 \\
\hline Finland & 29.574 & 32.893 & 33.036 & 32.969 \\
\hline Sverige & 72.581 & 84.854 & 84.769 & 85.809 \\
\hline Norge & 25.753 & 27.924 & 28.837 & 30.212 \\
\hline Kunst og k & & & & \\
\hline Danmark & 3.881 & 3.887 & 3.977 & 4.009 \\
\hline Finland & 2.146 & 2.250 & 2.101 & 2.489 \\
\hline Sverige & 5.931 & 6.137 & 6.027 & 6.513 \\
\hline Norge & $\ldots$ & $\ldots$ & $\ldots$ & $\ldots$ \\
\hline Mode & & & & \\
\hline Danmark & 14.610 & 15.105 & 13.480 & 13.142 \\
\hline Finland & 9.261 & 9.029 & 8.216 & 8.132 \\
\hline Sverige & 11.025 & 12.243 & 11.839 & 12.215 \\
\hline Norge & 5.802 & 6.126 & 5.418 & 5.522 \\
\hline Musik & & & & \\
\hline Danmark & 1.148 & 803 & 697 & 634 \\
\hline Finland & 763 & 782 & 779 & 719 \\
\hline Sverige & 1.597 & 1.853 & 1.724 & 1.627 \\
\hline Norge & 245 & 394 & 305 & 277 \\
\hline
\end{tabular}




\begin{tabular}{lrrrr} 
& \multicolumn{3}{c}{ Årsværk (Antal) } \\
& $\mathbf{2 0 0 7}$ & $\mathbf{2 0 0 8}$ & $\mathbf{2 0 0 9}$ & $\mathbf{2 0 1 0}$ \\
& & & & \\
Møbler og interiør & & & \\
Danmark & 18.171 & 17.399 & 12.983 & 11.434 \\
Finland & 9.405 & 9.455 & 8.392 & 7.734 \\
Sverige & 16.866 & 15.308 & 14.175 & 13.978 \\
Norge & 9.404 & 9.410 & 7.940 & 7.490 \\
Telekommunikationsudstyr, & & & & \\
radio og TV & & & & \\
Danmark & 13.375 & 11.795 & 11.096 & 10.616 \\
Finland & 35.043 & 35.014 & 32.371 & 29.487 \\
Sverige & 38.309 & 39.544 & 39.186 & 38.472 \\
Norge & 8.527 & 8.636 & 8.215 & 8.229 \\
Reklame & & & & \\
Danmark & 11.244 & 11.098 & 8.637 & 7.413 \\
Finland & 7.563 & 7.801 & 8.163 & 16.722 \\
Sverige & 17.690 & 18.090 & 17.068 & 3.530 \\
Norge & 4.182 & 3.947 & 3.619 & \\
\hline
\end{tabular}

\subsection{Gennemsnitlig beskæftigelse i kreative erhverv}

I Finland ligger den gennemsnitlige beskæftigelse pr. virksomhed i kreative erhverv på omkring 5 årsværk i perioden 2007-2010 (4,8 årsværk i 2010), hvilket er $8 \%$ højere end den gennemsnitlige beskæftigelse i øvrige markedsmæssige erhverv i landet (4,5 årsværk i 2010). Tendensen er den samme i alle årene 2007-2010.

I Danmark, Sverige og Norge beskæftiger de kreative virksomheder i gennemsnit færre årsværk end øvrige virksomheder.

I 2007 er beskæftigelsen således $15 \%$ lavere i kreative virksomheder end i øvrige virksomheder i Danmark, mens det tilsvarende tal er $50 \%$ i Sverige og $29 \%$ i Norge; i 2010 er tallene marginalt ændrede: beskæftigelsen er $19 \%$ lavere i kreative erhverv end øvrige erhverv i Danmark, mens det er en negativ forskel på $23 \%$ i Norge og $49 \%$ i Sverige. 
Figur 3. Udvikling i årsværk pr. virksomhed i kreative og alle erhverv. 20072010

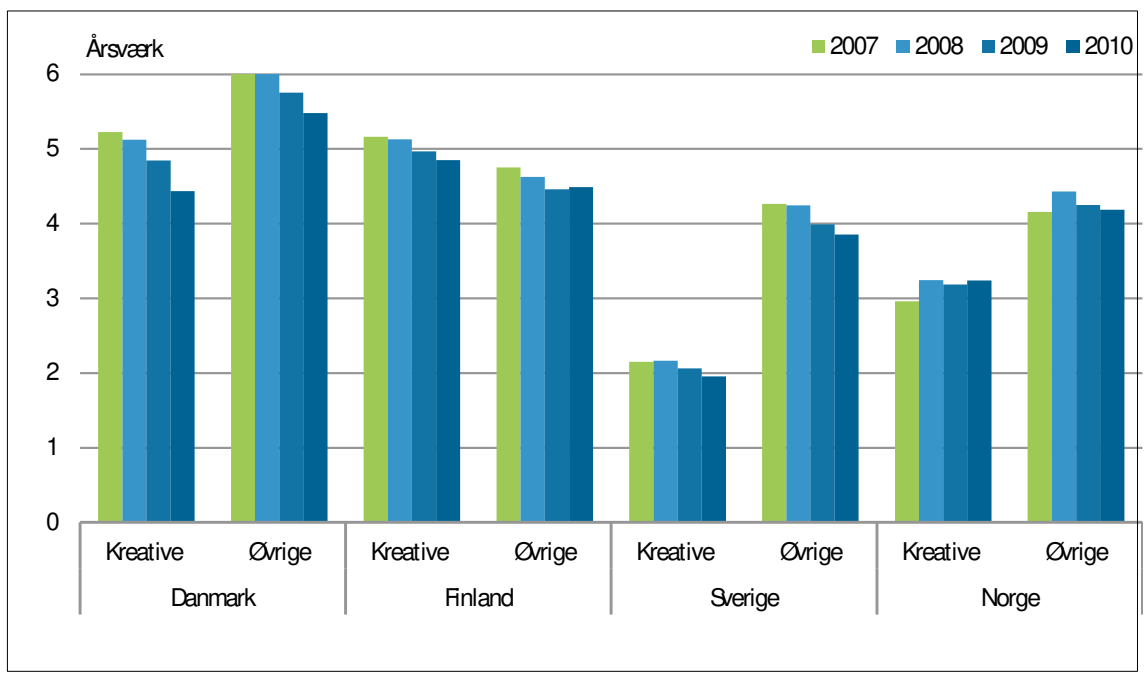

\subsection{Samlet beskæftigelse i kreative erhverv}

Udviklingen i beskæftigelsen i de kreative erhverv følger ikke udviklingen i landenes totale beskæftigelse. Fra 2007 til 2008 stiger antallet af beskæftigede i Danmark med 1,5\%, mens beskæftigelsen i kreative erhverv falder med 0,3\% i samme periode. I Finland stiger den samlede beskæftigelse i kreative erhverv med 2,2 \%, mens den samlede beskæftigelse kun stiger med 1,4\% fra 2007 til 2008.

I Sverige er udviklingen modsat; fra 2007 til 2008 stiger beskæftigelsen i landet med 2,6 \%, mens beskæftigelsen i kreative erhverv i samme periode stiger med 4,4\% I Norge er udviklingen mere homogen; beskæftigelsen i landet stiger med 13,3\%, mens de kreative erhvervs beskæftigelse stiger med $14,9 \%$

Fra 2008 til 2009 falder både den totale beskæftigelse og beskæftigelsen i de kreative erhverv i alle fire lande. I Danmark og Sverige falder beskæftigelsen i kreative erhverv dog mindre end den samlede beskæftigelse $(-11,3 \%$ samlet beskæftigelse og $-8,7 \%$ beskæftigelse i kreative erhverv i Danmark og -3,9\% samlet og -2 \% i kreative erhverv i Sverige). I Finland og Norge falder beskæftigelsen i kreative erhverv derimod mere end den samlede beskæftigelse, nemlig med 3,8 \% i Finland og 4,4 $\%$ i Norge.

I 2010 ses en stigning i beskæftigelsen i de kreative erhverv i Norge på $0,4 \%$ sammenlignet med året før, samtidig med at den samlede beskæftigelse i landet falder med 1,9 \% i samme periode. Omvendt forhol- 
der det sig for kreative erhverv i Finland, som mister 3,5 \% af beskæftigelsen fra 2009 til 2010, mens hele erhvervslivets beskæftigelse falder med 0,2 \% I Danmark udvikler beskæftigelsen i kreative erhverv sig som den samlede beskæftigelse i de markedsmæssige erhverv, mens beskæftigelsen i svenske kreative erhverv stagnerer, mens landets samlede beskæftigelse stiger med 0,8 \% i forhold til året før.

Figur 4. Udvikling i årsværk i kreative og alle erhverv. 2007-2010

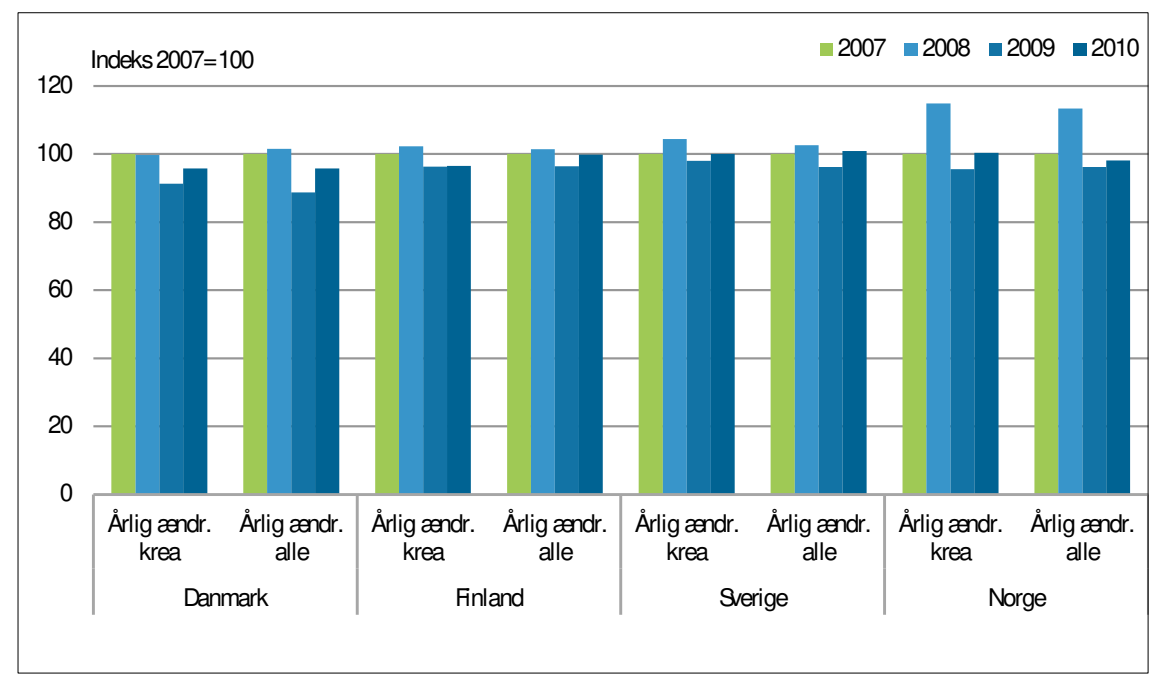

\subsection{Antal ansatte i kreative erhverv}

Datagrundlaget indeholder ikke oplysninger om deltidsansatte - i stedet beregnes et mål herfor ved sammenstilling af antal ansatte og antal årsværk i hvert erhverv (ratio).

Ratio for deltidsansatte beregnes som:

$$
\text { Antal årsværk }
$$

I 2007 er ratio mellem antallet af ansatte og årsværk lavere i kreative erhverv end i alle erhverv i alle fire lande; dette betyder, at der er flere deltidsansatte i de kreative erhverv end i øvrige erhverv.

Tendensen ændres fra 2008, hvor andelen af deltidsansatte er lige stor i kreative erhverv og øvrige erhverv i Danmark - i 2009 gør samme 
tendens sig gældende for Finland og Sverige. I 2009 er der til gengæld færre deltidsansatte i kreative erhverv end andre erhverv i Danmark.

\begin{tabular}{|c|c|c|c|c|c|c|c|c|}
\hline & \multicolumn{8}{|c|}{ Ratio ansat/årsværk } \\
\hline & & 2007 & & 2008 & & 2009 & & 2010 \\
\hline & Kreative & $\varnothing$ vrige & Kreative & $\varnothing$ vrige & Kreative & $\varnothing$ vrige & Kreative & $\varnothing$ vrige \\
\hline Danmark & 75,6 & 77,6 & 84,3 & 84,8 & 85,1 & 84,7 & 81,7 & 82,2 \\
\hline Finland & 87,2 & 88,7 & 86,9 & 87,6 & 85,9 & 86,2 & 86,0 & 86,9 \\
\hline Sverige & 73,7 & 76,5 & 75,0 & 76,7 & 77,1 & 77,3 & 75,4 & 76,1 \\
\hline Norge & 66,8 & 76,6 & 75,3 & 79,4 & 73,7 & 78,0 & 74,3 & 76,7 \\
\hline
\end{tabular}

I perioden 2007-2010 er der flest deltidsansatte inden for de kreative erhverv Reklame, Kunst og kunsthåndværk og Musik i Danmark, mens det i Finland er Design, der tegner sig for størst andel af deltidsansatte i perioden.

I Sverige er der flest deltidsansatte i Detail, Kunst og kunsthåndværk og Film og video, mens det er i Norge er Musik og Design, der har flest deltidsansatte blandt de kreative erhverv.

Tabel 4. Ratio mellem ansatte og årsværk. 2007 og 2010

\begin{tabular}{|c|c|c|c|c|c|c|c|c|}
\hline \multirow[t]{3}{*}{ Firmaer } & \multicolumn{8}{|c|}{ Ratio ansatte/årsværk } \\
\hline & \multicolumn{2}{|c|}{ Danmark } & \multicolumn{2}{|c|}{ Finland } & \multicolumn{2}{|c|}{ Sverige } & \multicolumn{2}{|c|}{ Norge } \\
\hline & 2007 & 2010 & 2007 & 2010 & 2007 & 2010 & 2007 & 2010 \\
\hline Alle erhverv & 77 & 82 & 88 & 87 & 76 & 76 & 75 & 76 \\
\hline$\varnothing$ vrige erhverv & 78 & 82 & 89 & 87 & 76 & 76 & 77 & 77 \\
\hline Arkitektur & 83 & 89 & 84 & 83 & 77 & 80 & 76 & 75 \\
\hline Bøger og presse & 77 & 76 & 88 & 88 & 75 & 76 & 44 & 82 \\
\hline Design & 75 & 81 & 70 & 65 & 66 & 68 & 43 & 43 \\
\hline Detail & 66 & 70 & 84 & 83 & 63 & 65 & 60 & 62 \\
\hline Film og video & 66 & 78 & 86 & 81 & 67 & 62 & 57 & 54 \\
\hline IT (hardware og salg) & 95 & 99 & 94 & 92 & 81 & 84 & 92 & 94 \\
\hline \multicolumn{9}{|l|}{ IT (programmering og } \\
\hline services) & 91 & 98 & 92 & 91 & 79 & 83 & 84 & 87 \\
\hline Kunst og kunsthåndværk & 57 & 68 & 76 & 77 & 63 & 63 & 0 & 0 \\
\hline Mode & 82 & 86 & 82 & 81 & 73 & 72 & 82 & 77 \\
\hline Musik & 70 & 64 & 78 & 71 & 71 & 71 & 41 & 48 \\
\hline Møbler og interiør & 89 & 90 & 84 & 83 & 80 & 81 & 90 & 83 \\
\hline \multicolumn{9}{|l|}{ Telekommunikationsudstyr, } \\
\hline radio og TV & 90 & 90 & 90 & 90 & 86 & 89 & 85 & 86 \\
\hline Reklame & 48 & 73 & 82 & 80 & 74 & 74 & 73 & 67 \\
\hline
\end{tabular}

Særligt det kreative erhverv Musik beskæftiger flere deltids- end fuldtidsansatte i Danmark og Norge, hvor ratio mellem ansatte og årsværk ligger på henholdsvis 64 og 48 i 2010. Design har derimod flest deltidsansatte i Finland og Sverige i 2010. 
Branchen IT (hardware og engroshandel) beskæftiger derimod næsten kun fuldtidsansatte i Danmark, Finland og Norge. I Sverige er det Radio og TV, som har den laveste andel af deltidsansatte blandt kreative erhverv.

Der er næsten 20.000 virksomheder med 0 årsværk i kreative erhverv i Danmark. Det svarer til knap $52 \%$ af alle virksomheder i kreative erhverv i 2010.

Dette indikerer, at der er en relativt stor andel af selvstændige erhvervsdrivende uden ansatte blandt virksomhederne i de kreative erhverv. Andelen er stabil i perioden 2007-2010. Tilsvarende oplysninger om Finland, Norge og Sverige foreligger ikke. 


\section{Omsætning i kreative erhverv}

De nationale erhvervsstatistikker opgør omsætningen for alle erhverv uden at tage højde for input og output. Dette medfører, at omsætningen knyttet til en given vare kan indgå i opgørelsen af den samlede omsætning flere gange, idet varen gennemgår en proces fra eksempelvis produktion til engros- og detailsalg.

Omsætningen i markedsmæssige erhverv udgør i 2010 næsten 3 bio. DKK i Danmark, over 4,5 bio. NOK i Norge og over 6,5 bio. SEK i Sverige. I Finland ligger de markedsmæssige erhvervs samlede omsætning i 2010 på næsten 360 mia. EUR.

I Danmark har omsætningen i kreative erhverv udgjort 12-13\% af den samlede omsætning i markedsmæssige erhverv i perioden 20072010. Andelen faldt med næsten $1 \%$ i 2008 for derefter at stige igen er $12,6 \%$ af den samlede omsætning i 2010.

Tabel 5. Omsætning i kreative og øvrige virksomheder. 2007-2010. Løbende priser

\begin{tabular}{|c|c|c|c|c|c|c|c|}
\hline & \multicolumn{4}{|c|}{ Omsætning (Landets egen valuta, mio.) } & \multicolumn{3}{|c|}{ Årlig ændring (\%) } \\
\hline & 2007 & 2008 & 2009 & 2010 & 2007 & 2008 & 2009 \\
\hline & & & & & -2008 & -2009 & -2010 \\
\hline \multicolumn{8}{|c|}{ Alle erhverv } \\
\hline Danmark & 3.077 .210 & 3.190 .634 & 2.759 .160 & 2.855 .086 & 3,6 & $-15,6$ & 3,4 \\
\hline Finland & 374.588 & 396.591 & 336.217 & 358.909 & 5,5 & $-18,0$ & 6,3 \\
\hline Sverige & 6.340 .124 & 6.617 .000 & 6.060 .666 & 6.535 .501 & 4,2 & $-9,2$ & 7,3 \\
\hline Norge & 3.178 .508 & 4.791 .573 & 4.297.714 & 4.514.299 & 33,7 & $-11,5$ & 4,8 \\
\hline \multicolumn{8}{|c|}{ Kreative erhverv } \\
\hline Danmark & 393.211 & 383.281 & 354.943 & 360.158 & $-2,6$ & $-8,0$ & 1,4 \\
\hline Finland & 65.686 & 66.510 & 55.646 & 56.457 & 1,2 & $-19,5$ & 1,4 \\
\hline Sverige & 869.257 & 929.818 & 891.299 & 929.049 & 6,5 & $-4,3$ & 4,1 \\
\hline Norge & 323.230 & 332.482 & 319.871 & 330.841 & 2,8 & $-3,9$ & 3,3 \\
\hline \multicolumn{8}{|c|}{$\emptyset$ vrige erhverv } \\
\hline Danmark & 2.683.999 & 2.807 .353 & 2.404 .217 & 2.494.929 & 4,4 & $-16,8$ & 3,6 \\
\hline Finland & 308.902 & 330.081 & 280.557 & 302.437 & 6,4 & $-17,7$ & 7,2 \\
\hline Sverige & 5.470 .867 & 5.687 .182 & 5.169 .366 & 5.606 .453 & 3,8 & $-10,0$ & 7,8 \\
\hline Norge & 2.855 .278 & 4.459.091 & 3.977 .842 & 4.183.457 & 36,0 & $-12,1$ & 4,9 \\
\hline
\end{tabular}


I Finland har den samlede omsætning i de kreative virksomheder været faldende igennem hele perioden og ligger i 2010 på $15,7 \%$ af den samlede omsætning i landets virksomheder.

Finland er dermed det eneste af de fire lande, hvor omsætningen i kreative erhverv falder i perioden 2007-2010.

Omsætningen i de svenske kreative erhverv har været stigende i perioden 2007-2009, svarende til en samlet stigning på $1 \%$, I 2010 falder omsætningsandelen dog lidt og den samlede omsætning i kreative erhverv udgør således 14,2 \% af den samlede omsætning i landet i 2010. Andelen af virksomheder i de kreative erhverv i Sverige er steget fra $25,1 \%$ i 2007 til $25,6 \%$ i 2010.

Figur 5. Andel af omsætning i kreative erhverv og øvrige erhverv. 2007 og 2010

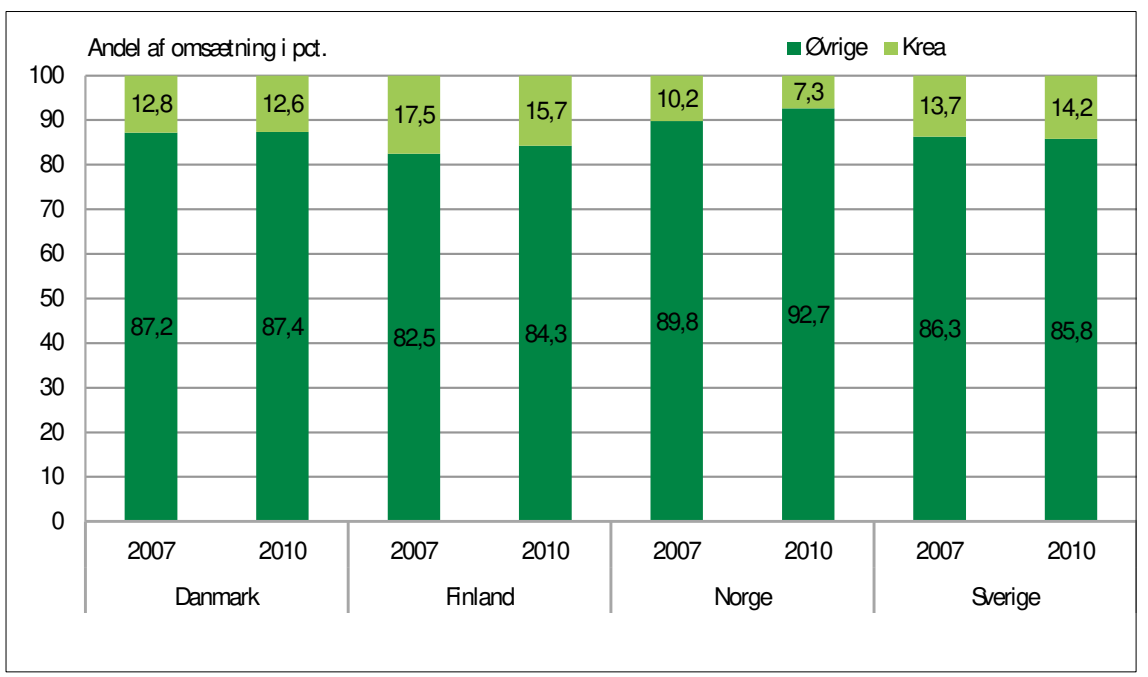

Kreative erhverv i Norge oplevede et fald i omsætningsandelen fra 2007 til 2008 på næsten $3 \%$ Fra 2007 til 2010 er den samlede omsætning i kreative erhverv steget med 2,4 \% i Norge samtidig med en stor stigning i omstigningen i øvrige erhverv. De kreative erhvervs omsætningsandel i landet udgør således 7,3 \% i 2010.

De kreative erhverv, som beskæftiger sig med produktions- og handelsorienterede aktiviteter, genererer ikke overraskende mest omsætning i alle fire lande.

Telekommunikationsudstyr, radio og TV er den enkelte kreative erhvervsgruppe, som generer mest omsætning i Finland og Sverige i 20072010. I Finland ligger omsætningen på 10,7 \% af de finske virksomheders samlede omsætning i 2007, men falder til 8,7 \% i 2010. I Sverige udgør omsætningen i dette erhverv 3,1 \% igennem hele perioden 2007-2010. 
I Danmark og Norge udgør omsætningen i Telekommunikationsudstyr, radio og $T V$ ca. $1 \%$ af den samlede omsætning i markedsmæssige erhverv, mens Detail er det kreative erhverv, der tegner sig for den største andel af den samlede omsætning blandt de kreative erhverv med 2-3\% igennem perioden.

Tabel 6. Omsætning i kreative erhverv. 2007-2010

\begin{tabular}{|c|c|c|c|c|}
\hline & \multicolumn{3}{|c|}{ Omsætning (Landets egen valuta, mio.) } & \multirow[b]{2}{*}{2010} \\
\hline & 2007 & 2008 & 2009 & \\
\hline \multicolumn{5}{|c|}{ Kreative erhverv } \\
\hline Danmark & 393.211 & 383.281 & 354.943 & 360.158 \\
\hline Finland & 65.686 & 66.510 & 55.646 & 56.457 \\
\hline Sverige & 869.257 & 929.818 & 891.299 & 929.049 \\
\hline Norge & 323.230 & 332.482 & 319.871 & 330.841 \\
\hline \multicolumn{5}{|c|}{ Heraf:Arkitektur } \\
\hline Danmark & 7.256 & 7.718 & 6.181 & 5.700 \\
\hline Finland & 347 & 363 & 325 & 330 \\
\hline Sverige & 6.211 & 6.714 & 6.643 & 6.577 \\
\hline Norge & 5.232 & 5.742 & 5.110 & 5.329 \\
\hline \multicolumn{5}{|c|}{ Bøger og presse } \\
\hline Danmark & 58.466 & 57.214 & 49.353 & 48.043 \\
\hline Finland & 6.194 & 6.198 & 5.613 & 5.707 \\
\hline Sverige & 110.747 & 112.866 & 105.600 & 108.655 \\
\hline Norge & 66.467 & 66.382 & 62.161 & 63.037 \\
\hline \multicolumn{5}{|l|}{ Design } \\
\hline Danmark & 4.197 & 4.701 & 4.058 & 4.275 \\
\hline Finland & 122 & 150 & 163 & 153 \\
\hline Sverige & 11.259 & 12.409 & 10.084 & 10.757 \\
\hline Norge & 2.561 & 2.845 & 2.709 & 3.019 \\
\hline \multicolumn{5}{|l|}{ Detail } \\
\hline Danmark & 82.490 & 81.118 & 76.696 & 76.107 \\
\hline Finland & 6.112 & 6.388 & 6.155 & 6.157 \\
\hline Sverige & 177.851 & 174.231 & 178.524 & 178.427 \\
\hline Norge & 85.397 & 87.054 & 87.109 & 89.233 \\
\hline \multicolumn{5}{|c|}{ Film og video } \\
\hline Danmark & 6.032 & 6.465 & 7.075 & 7.023 \\
\hline Finland & 340 & 375 & 327 & 336 \\
\hline Sverige & 19.982 & 20.066 & 20.448 & 20.833 \\
\hline Norge & 4.841 & 5.150 & 5.057 & 5.228 \\
\hline \multicolumn{5}{|c|}{ IT (hardware og engroshandel) } \\
\hline Danmark & 39.015 & 36.872 & 36.234 & 36.751 \\
\hline Finland & 3.242 & 3.246 & 2.856 & 2.993 \\
\hline Sverige & 72.345 & 68.722 & 62.139 & 64.691 \\
\hline Norge & 31.016 & 32.144 & 29.674 & 30.158 \\
\hline \multicolumn{5}{|c|}{ IT (programmering og services) } \\
\hline Danmark & 50.608 & 52.999 & 54.258 & 55.732 \\
\hline Finland & 4.022 & 4.820 & 4.652 & 4.693 \\
\hline Sverige & 129.582 & 153.944 & 144.793 & 151.749 \\
\hline Norge & 44.269 & 50.643 & 50.707 & 55.322 \\
\hline \multicolumn{5}{|c|}{ Kunst og kunsthåndværk } \\
\hline Danmark & 2.399 & 2.497 & 2.567 & 2.746 \\
\hline Finland & 141 & 201 & 185 & 215 \\
\hline Sverige & 11.000 & 11.543 & 11.528 & 12.138 \\
\hline Norge & 0 & 0 & 0 & 0 \\
\hline
\end{tabular}




\begin{tabular}{|c|c|c|c|c|}
\hline & \multicolumn{3}{|c|}{ Omsætning (Landets egen valuta, mio.) } & \multirow[b]{2}{*}{2010} \\
\hline & 2007 & 2008 & 2009 & \\
\hline \multicolumn{5}{|l|}{ Mode } \\
\hline Danmark & 47.032 & 48.752 & 44.899 & 52.871 \\
\hline Finland & 1.586 & 1.671 & 1.537 & 1.570 \\
\hline Sverige & 60.831 & 94.965 & 98.419 & 107.481 \\
\hline Norge & 18.822 & 19.987 & 19.109 & 20.467 \\
\hline \multicolumn{5}{|l|}{ Musik } \\
\hline Danmark & 1.805 & 1.258 & 1.274 & 1.281 \\
\hline Finland & 128 & 129 & 120 & 118 \\
\hline Sverige & 3.401 & 4.136 & 3.996 & 4.258 \\
\hline Norge & 1.051 & 1.100 & 1.073 & 1.104 \\
\hline \multicolumn{5}{|c|}{ Møbler og interiør } \\
\hline Danmark & 34.888 & 31.566 & 26.094 & 24.873 \\
\hline Finland & 1.667 & 1.603 & 1.314 & 1.444 \\
\hline Sverige & 38.200 & 34.893 & 31.363 & 33.188 \\
\hline Norge & 19.294 & 18.688 & 16.872 & 16.546 \\
\hline \multicolumn{5}{|c|}{$\begin{array}{l}\text { Telekommunikationsudstyr, } \\
\text { radio og TV }\end{array}$} \\
\hline Danmark & 40.680 & 33.648 & 31.330 & 30.852 \\
\hline Finland & 40.206 & 39.745 & 30.860 & 31.153 \\
\hline Sverige & 195.281 & 202.609 & 187.918 & 199.593 \\
\hline Norge & 36.162 & 35.117 & 33.640 & 34.125 \\
\hline \multicolumn{5}{|l|}{ Reklame } \\
\hline Danmark & 18.342 & 18.472 & 14.922 & 13.901 \\
\hline Finland & 1.579 & 1.621 & 1.539 & 1.587 \\
\hline Sverige & 32.568 & 32.719 & 29.845 & 30.701 \\
\hline Norge & 8.118 & 7.630 & 6.650 & 7.273 \\
\hline
\end{tabular}

I Norge er Bøger og presse den næststørste kreative erhvervsgruppe igennem hele perioden 2007-2010, hvor omsætningen udgør mellem $1,4 \%$ og 2,1 \% af den samlede omsætning i landet.

I Danmark og Finland har Bøger og presse den næststørste andel af den samlede omsætning i 2007 og 2008 (1,6 - 1,9\%).

I Sverige er det næststørste kreative erhverv målt på omsætning $D e-$ tail med knap $3 \%$ af den samlede omsætning igennem hele perioden $(2,7 \%$ i 2010$)$.

\subsection{Omsætning pr. virksomhed}

Gennemsnitlig omsætning pr. virksomhed i danske øvrige erhverv er faldet mindre end i de kreative erhverv, nemlig kun med 4,3\% Tilsvarende er gennemsnitlig omsætning i de finske øvrige erhverv kun faldet med 5,4\% i perioden 2007-2010 - i samme periode faldt omsætning pr. virksomhed blandt kreative erhverv med $15 \%$

I Sverige er øvrige erhvervs gennemsnitlige omsætning faldet mere end $\mathrm{i}$ de kreative erhverv (6,3 \% i øvrige erhverv og $5 \%$ i kreative erhverv). 
Øvrige erhverv i Norge har oplevet en stigning i den gennemsnitlige omsætning på 38,4 \%, hvilket er markant højere end 1,6 \%, som er stigningen i den gennemsnitlige omsætning i de kreative erhverv i perioden 2007-2010.

Figur 7. Udvikling i omsætning pr. virksomhed i kreative og øvrige erhverv. 2007-2010

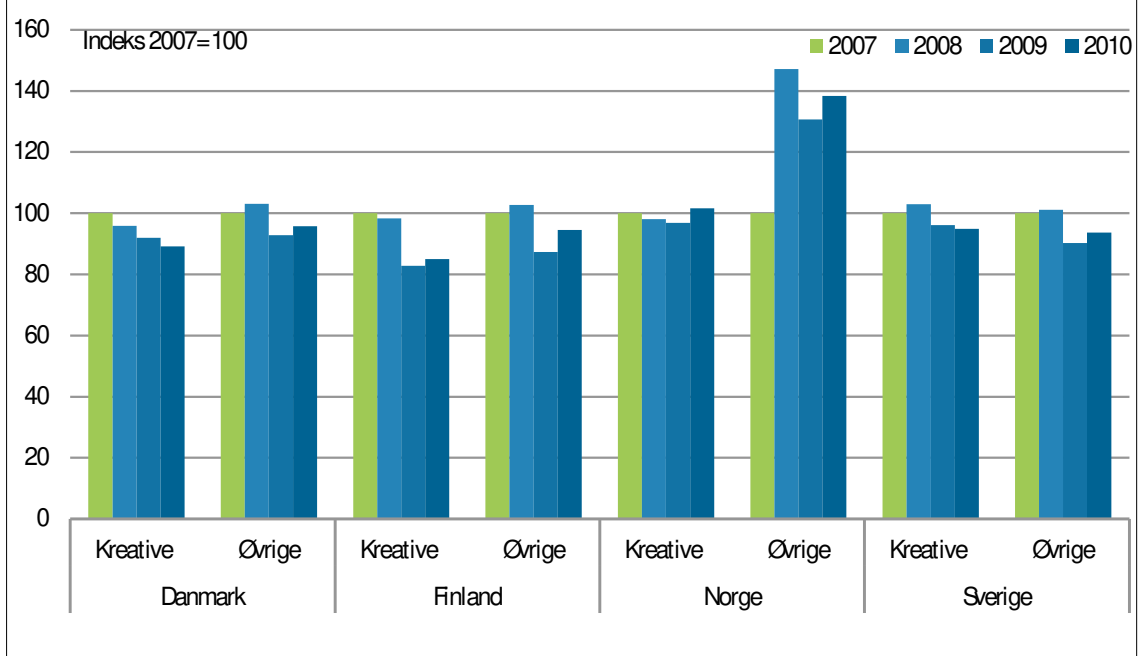





\section{Antal virksomheder $\mathrm{i}$ kreative erhverv}

Antallet af aktive virksomheder i kreative erhverv i Norden udgør mellem 33.000 (Finland) og 167.000 (Sverige) i 2010. Dette svarer til mellem 11 og $26 \%$ af alle aktive virksomheder i markedsmæssige erhverv i de respektive lande.

Antallet af virksomheder i kreative erhverv voksede i alle fire lande fra 2007-2008 og også i 2009 i Finland, Sverige og Norge. I Danmark faldt antallet af virksomheder i kreative erhverv med ca. 3,6 \% fra 2008 til 2009 - dog faldt det samlede antal af virksomheder i landet mere, nemlig næsten $5 \%$

Fra 2009 til 2010 var antallet af kreative virksomheder igen stigende i Danmark, hvor antallet af virksomheder i kreative erhverv er højere end i 2007 og 2008. I Finland og Norge falder antallet af virksomheder i kreative erhverv fra 2009 til 2010, men der er dog stadig flere virksomheder i kreative erhverv end i 2007.

I Sverige bliver der fortsat flere virksomheder i de kreative erhverv; i 2010 er der således over 12 \% flere kreative virksomheder end i 2007, mens antallet af alle virksomheder i markedsmæssige erhverv kun er steget med $0,1 \%$ i samme periode. 
Tabel 7. Antal virksomheder i kreative og øvrige erhverv. 2007-2010

\begin{tabular}{|c|c|c|c|c|c|c|c|}
\hline & \multicolumn{4}{|c|}{ Firmaer (Antal) } & \multicolumn{3}{|c|}{ Årlig ændring (\%) } \\
\hline & 2007 & 2008 & 2009 & 2010 & $\begin{array}{r}2007 \\
-2008\end{array}$ & $\begin{array}{r}2008 \\
-2009\end{array}$ & $\begin{array}{r}2009 \\
-2010\end{array}$ \\
\hline \multicolumn{8}{|c|}{ Alle erhverv } \\
\hline Danmark & 225.281 & 228.693 & 217.989 & 220.830 & 1,5 & $-4,9$ & 1,3 \\
\hline Finland & 308.917 & 320.952 & 320.682 & 318.951 & 3,7 & $-0,1$ & $-0,5$ \\
\hline Sverige & 594.851 & 612.788 & 625.631 & 655.532 & 2,9 & 2,1 & 4,6 \\
\hline Norge & 264.169 & 279.818 & 279.859 & 277.546 & 5,6 & 0,0 & $-0,8$ \\
\hline \multicolumn{8}{|c|}{ Kreative erhverv } \\
\hline Danmark & 37.387 & 38.016 & 36.692 & 38.390 & 1,7 & $-3,6$ & 4,4 \\
\hline Finland & 33.235 & 34.205 & 33.988 & 33.622 & 2,8 & $-0,6$ & $-1,1$ \\
\hline Sverige & 149.023 & 154.763 & 158.871 & 167.742 & 3,7 & 2,6 & 5,3 \\
\hline Norge & 41.102 & 43.108 & 41.974 & 41.420 & 4,7 & $-2,7$ & $-1,3$ \\
\hline \multicolumn{8}{|c|}{$\emptyset$ vrige erhverv } \\
\hline Danmark & 187.894 & 190.677 & 181.297 & 182.440 & 1,5 & $-5,2$ & 0,6 \\
\hline Finland & 275.682 & 286.747 & 286.694 & 285.329 & 3,9 & 0,0 & $-0,5$ \\
\hline Sverige & 445.828 & 458.025 & 466.760 & 487.790 & 2,7 & 1,9 & 4,3 \\
\hline Norge & 223.067 & 236.710 & 237.885 & 236.126 & 5,8 & 0,5 & $-0,7$ \\
\hline
\end{tabular}

Antallet af virksomheder i kreative erhverv i Norden har været relativt stabil i perioden 2007-2010. Andelen af kreative virksomheder er højest i Sverige med over $25 \%$ af alle aktive virksomheder og lavest i Finland med knap $11 \%$

Figur 8. Andel af kreative og øvrige virksomheder. 2007 og 2010

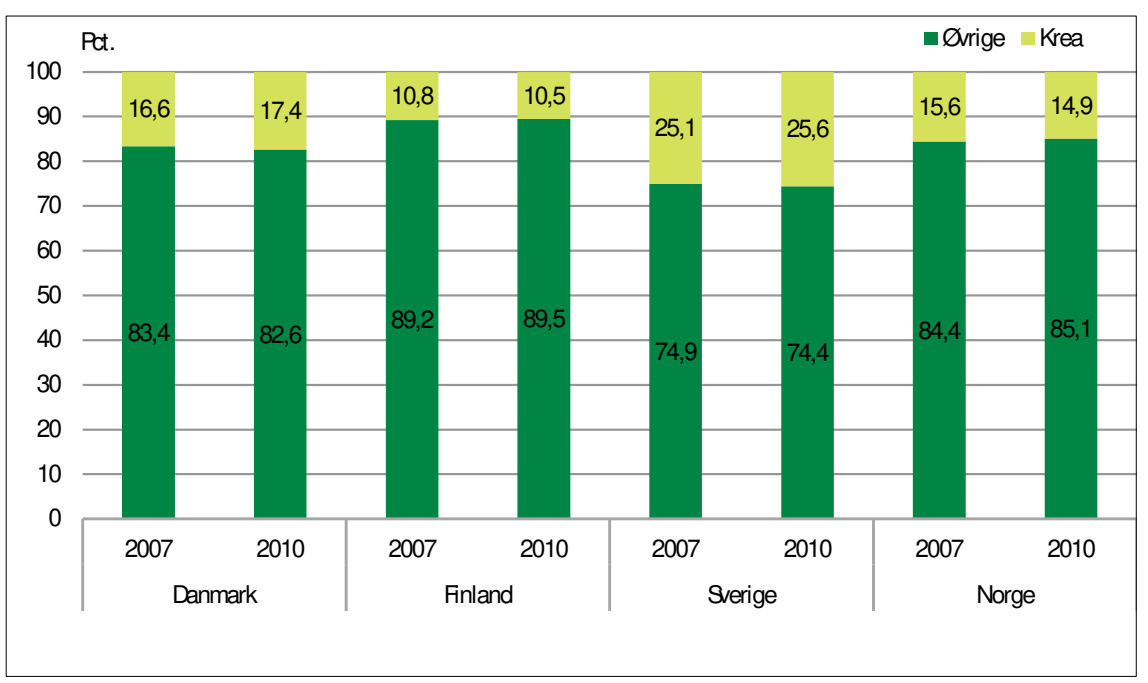

Det kreative erhverv med størst andel af aktive virksomheder i perioden 2007-2010 var Detailbranchen i Danmark (ca. 5 \%), Norge (ca. 4 \%). og Finland (ca. $3 \%$ ). I Sverige er det største kreative erhverv IT (programmering og services), som udgør over $5 \%$ af alle aktive virksomheder i markedsmæssige erhverv i årene 2007-2010. 
Tabel 8. Antal virksomheder i kreative erhverv. 2007-2010

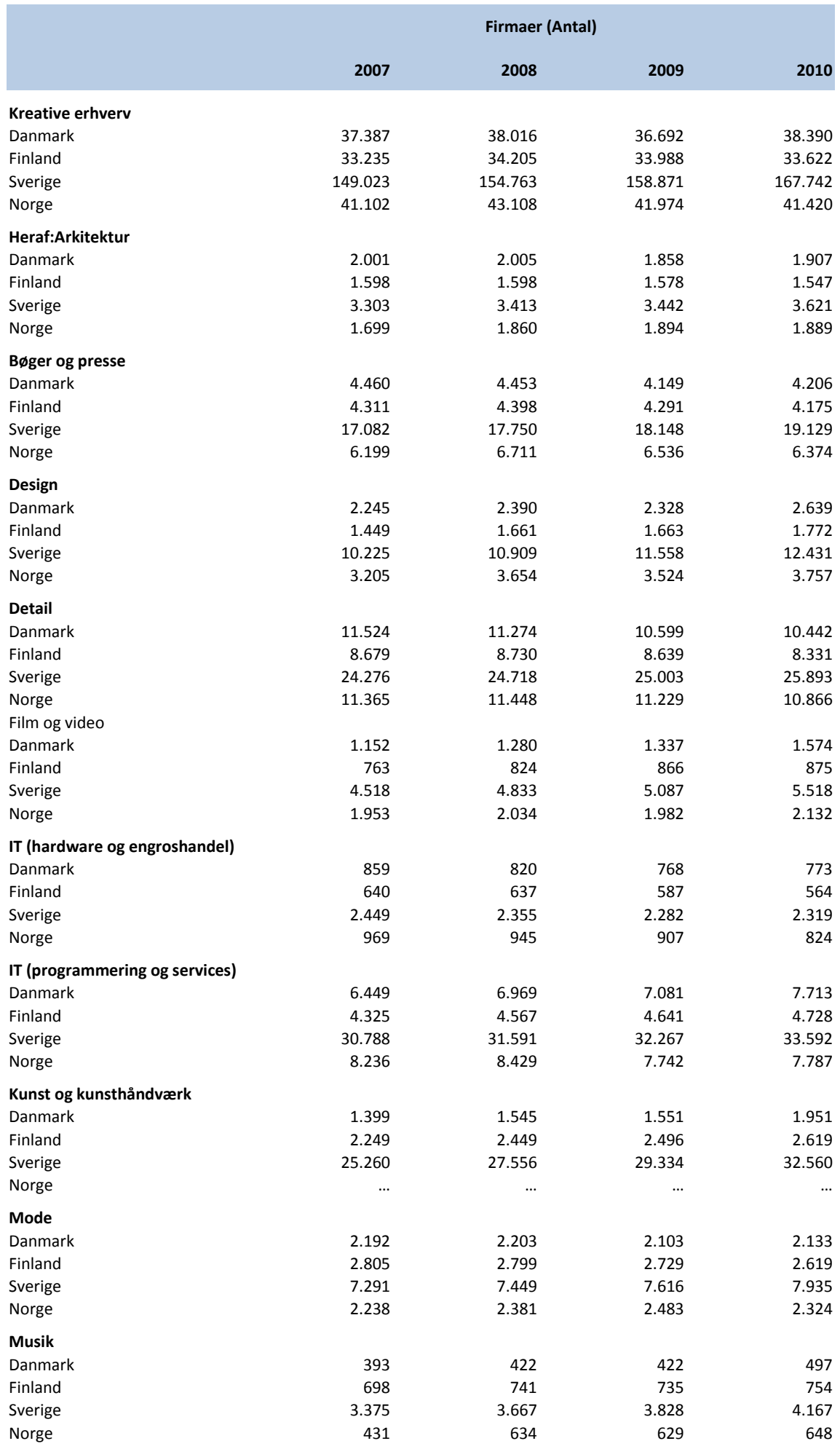




\begin{tabular}{|c|c|c|c|c|}
\hline & \multicolumn{4}{|c|}{ Firmaer (Antal) } \\
\hline & 2007 & 2008 & 2009 & 2010 \\
\hline \multicolumn{5}{|c|}{ Møbler og interi $\varnothing r$} \\
\hline Danmark & 1.435 & 1.428 & 1.342 & 1.347 \\
\hline Finland & 2.298 & 2.249 & 2.089 & 1.982 \\
\hline Sverige & 5.421 & 5.400 & 5.297 & 5.371 \\
\hline Norge & 1.984 & 2.097 & 2.202 & 2.003 \\
\hline \multicolumn{5}{|c|}{$\begin{array}{l}\text { Telekommunikationsudstyr, } \\
\text { radio og TV }\end{array}$} \\
\hline Danmark & 683 & 696 & 669 & 639 \\
\hline Finland & 495 & 493 & 483 & 467 \\
\hline Sverige & 2.214 & 2.214 & 2.211 & 2.275 \\
\hline Norge & 690 & 698 & 672 & 617 \\
\hline \multicolumn{5}{|l|}{ Reklame } \\
\hline Danmark & 2.595 & 2.531 & 2.485 & 2.569 \\
\hline Finland & 2.925 & 3.059 & 3.191 & 3.189 \\
\hline Sverige & 12.821 & 12.908 & 12.798 & 12.931 \\
\hline Norge & 2.133 & 2.217 & 2.174 & 2.199 \\
\hline
\end{tabular}

IT (programmering og services) er det næststørste kreative erhverv i Danmark i årene 2007-2010 med omkring $3 \%$ af landets virksomheder. Det samme gør sig gældende i Norge i 2007-2010 (ligeledes ca. $3 \%$ ).

I Finland er Bøger og presse og IT (programmering og services) lige store og udgør $1,4 \%$ af landets virksomheder og er dermed de næststørste kreative erhverv i 2007 og 2008, men antallet af virksomheder i Bøger og presse falder i 2009, mens IT (programmering og services) vokser og bliver det næststørste kreative erhverv i 2009. I 2010 udgør IT (programmering og services) 1,5\% af virksomhederne i Finland. 


\section{Virksomheders størrelse i kreative erhverv}

I denne rapport anvendes betegnelserne mikro-, små, mellemstore og store virksomheder.

Mikrovirksomheder dækker over virksomheder med 0-9 ansatte (målt som årsværk), som i analysen opdeles i henholdsvis 0-4 og 5-9 ansatte. Små virksomheder defineres som virksomheder med 10-49 ansatte og opdeles i grupperne 10-24 og 25-49 ansatte. Mellemstore virksomheder har 50-99 ansatte, mens store virksomheder har mindst 100 ansatte.

\section{Antal virksomheder fordelt på virksomhedsstørrelser}

Erhvervsstrukturen i den kreative sektor svarer i store træk til erhvervsstrukturen i øvrige markedsmæssige erhverv i alle fire lande; de fleste af virksomhederne i de kreative erhverv er mikrovirksomheder.

Andelen af de mindste (mikro-) virksomheder med 0-4 årsværk er dog større blandt de kreative erhverv end øvrige erhverv i Danmark, Norge og Sverige i årene 2007-2010.

I Danmark er antallet af mikrovirksomheder i kreative erhverv over 35.000 i 2010, mens samme størrelsesgruppe udgør over 31.000 i Finland og mere end 38.000 i Norge. I Sverige er der over 162.000 mikrovirksomheder i kreative erhverv. ${ }^{6}$

Samtidig er der 214 store virksomheder med mindst 100 årsværk i de kreative erhverv i Danmark i 2010; i Finland og Norge er antallet henholdsvis 180 og 197 virksomheder, mens der i Sverige er 303 virksomheder i samme gruppe.

\footnotetext{
${ }^{6}$ Den svenske statistik er underlagt fortrolighedskrav, således at knap 1,4 \% af virksomhederne i de kreative erhverv i 2007 ikke kan placeres i en størrelsesgruppe; i 2010 er tallet på 0,8 \% Disse virksomheder dækker i perioden 2007-2010 over 17-19\% af beskæftigelsen og 13-17 \% af den samlede omsætning i landets kreative erhverv.
} 
I Danmark og Finland falder antallet af store virksomheder i kreative erhverv i perioden 2007-2010, mens det omvendte gør sig gældende i Sverige og Norge.

Tabel 9. Kreative erhvervs virksomheder fordelt på virksomhedsstørrelse. 2007 og 2010

\begin{tabular}{|c|c|c|c|c|c|c|c|}
\hline & \multicolumn{4}{|c|}{ Firmaer (Antal) } & \multicolumn{3}{|c|}{ Årlig ændring (\%) } \\
\hline & 2007 & 2008 & 2009 & 2010 & 2007 & 2008 & 2009 \\
\hline & & & & & -2008 & -2009 & -2010 \\
\hline \multicolumn{8}{|c|}{ Alle kreative virksomheder } \\
\hline Danmark & 37.387 & 38.016 & 36.692 & 38.390 & 1,7 & $-3,5$ & 4,6 \\
\hline Finland & 33.235 & 34.205 & 33.988 & 33.622 & 2,9 & $-0,6$ & $-1,1$ \\
\hline Norge & 41.102 & 43.108 & 41.974 & 41.420 & 4,9 & $-2,6$ & $-1,3$ \\
\hline Sverige & 149.023 & 154.763 & 158.871 & 167.742 & 3,9 & 2,7 & 5,6 \\
\hline \multicolumn{8}{|l|}{ Heraf: } \\
\hline \multicolumn{8}{|c|}{ Mikro (0-9 årsværk) } \\
\hline Danmark & 34.100 & 34.685 & 33.771 & 35.654 & 1,7 & $-2,6$ & 5,6 \\
\hline Finland & 31.079 & 32.053 & 31.888 & 31.566 & 3,1 & $-0,5$ & $-1,0$ \\
\hline Norge & 38.186 & 40.139 & 39.028 & 38.544 & 5,1 & $-2,8$ & $-1,2$ \\
\hline Sverige & 142.745 & 149.580 & 153.687 & 162.536 & 4,8 & 2,7 & 5,8 \\
\hline \multicolumn{8}{|c|}{ Små (10-49 årsværk) } \\
\hline Danmark & 2.729 & 2.759 & 2.424 & 2.269 & 1,1 & $-12,1$ & $-6,4$ \\
\hline Finland & 1.777 & 1.772 & 1.727 & 1.699 & $-0,3$ & $-2,5$ & $-1,6$ \\
\hline Norge & 2.501 & 2.530 & 2.505 & 2.430 & 1,2 & $-1,0$ & $-3,0$ \\
\hline Sverige & 3.592 & 3.436 & 3.284 & 3.259 & $-4,3$ & $-4,4$ & $-0,8$ \\
\hline \multicolumn{8}{|c|}{ Mellemstore (90-99 årsværk) } \\
\hline Danmark & 310 & 322 & 270 & 253 & 3,9 & $-16,1$ & $-6,3$ \\
\hline Finland & 188 & 182 & 182 & 177 & $-3,2$ & 0,0 & $-2,7$ \\
\hline Norge & 226 & 245 & 243 & 249 & 8,4 & $-0,8$ & 2,5 \\
\hline Sverige & 356 & 368 & 355 & 348 & 3,4 & $-3,5$ & $-2,0$ \\
\hline \multicolumn{8}{|c|}{ Store (100+ årsværk) } \\
\hline Danmark & 248 & 250 & 227 & 214 & 0,8 & $-9,2$ & $-5,7$ \\
\hline Finland & 191 & 198 & 191 & 180 & 3,7 & $-3,5$ & $-5,8$ \\
\hline Norge & 189 & 194 & 198 & 197 & 2,6 & 2,1 & $-0,5$ \\
\hline Sverige & 289 & 298 & 300 & 303 & 3,1 & 0,7 & 1,0 \\
\hline
\end{tabular}

Svenske tal indgår delvis grundet diskretionering.

I 2010 udgør virksomheder med 0-9 årsværk mellem $93 \%$ af alle virksomhederne i den kreative sektor i Danmark, mens andelen i Finland og Norge ligger på $94 \%$ og $93 \%$ henholdsvis. Mikrovirksomheder i Sverige udgør i 2010 omkring $97 \%$ af alle virksomheder i de kreative erhverv. 
Tabel 10. Andel af virksomheder i størrelsesgrupper. Kreative og øvrige erhverv. 2007-2010

\begin{tabular}{|c|c|c|c|c|c|c|c|c|}
\hline & \multicolumn{8}{|c|}{ Andel } \\
\hline & \multicolumn{2}{|c|}{ Danmark } & \multicolumn{2}{|c|}{ Finland } & \multicolumn{2}{|c|}{ Norge } & \multicolumn{2}{|c|}{ Sverige } \\
\hline & Kreative & $\varnothing$ vrige & Kreative & $\emptyset$ vrige & Kreative & $\emptyset$ vrige & Kreative & $\varnothing$ vrige \\
\hline \multicolumn{9}{|l|}{2007} \\
\hline Mikro, 0-9 årsværk & 91,2 & 90,5 & 93,5 & 94,3 & 92,9 & 91,5 & 95,8 & 94,3 \\
\hline Små, 10-49 årsværk & 7,3 & 7,9 & 5,3 & 4,8 & 6,1 & 7,3 & 2,4 & 4,7 \\
\hline Mellemstore, 50-99 årsværk & 0,8 & 0,9 & 0,6 & 0,5 & 0,5 & 0,7 & 0,2 & 0,5 \\
\hline Store, 100+årsværk & 0,7 & 0,7 & 0,6 & 0,5 & 0,5 & 0,6 & 0,2 & 0,5 \\
\hline \multicolumn{9}{|l|}{2008} \\
\hline Mikro, 0-9 årsværk & 91,2 & 90,5 & 93,7 & 94,5 & 93,1 & 91,5 & 96,7 & 94,3 \\
\hline Små, 10-49 årsværk & 7,3 & 7,9 & 5,2 & 4,6 & 5,9 & 7,2 & 2,2 & 4,8 \\
\hline Mellemstore, 50-99 årsværk & 0,8 & 0,9 & 0,5 & 0,5 & 0,6 & 0,7 & 0,2 & 0,5 \\
\hline Store, 100+årsværk & 0,7 & 0,7 & 0,6 & 0,5 & 0,5 & 0,6 & 0,2 & 0,4 \\
\hline \multicolumn{9}{|l|}{2009} \\
\hline Mikro, 0-9 årsværk & 92,0 & 91,3 & 93,8 & 94,5 & 93,0 & 91,6 & 96,7 & 94,5 \\
\hline Små, 10-49 årsværk & 6,6 & 7,3 & 5,1 & 4,6 & 6,0 & 7,2 & 2,1 & 4,6 \\
\hline Mellemstore, 50-99 årsværk & 0,7 & 0,8 & 0,5 & 0,4 & 0,6 & 0,6 & 0,2 & 0,5 \\
\hline Store, 100+årsværk & 0,6 & 0,7 & 0,6 & 0,5 & 0,5 & 0,6 & 0,2 & 0,4 \\
\hline \multicolumn{9}{|l|}{2010} \\
\hline Mikro, 0-9 årsværk & 92,9 & 91,8 & 93,9 & 94,5 & 93,1 & 91,6 & 96,9 & 94,6 \\
\hline Små, 10-49 årsværk & 5,9 & 6,8 & 5,1 & 4,6 & 5,9 & 7,2 & 1,9 & 4,5 \\
\hline Mellemstore, 50-99 årsværk & 0,7 & 0,7 & 0,5 & 0,5 & 0,6 & 0,6 & 0,2 & 0,5 \\
\hline Store, $100+$ årsværk & 0,6 & 0,6 & 0,5 & 0,5 & 0,5 & 0,6 & 0,2 & 0,4 \\
\hline
\end{tabular}

Svenske tal indgår delvis grundet diskretionering.

I perioden 2007-2010 er andelen af virksomheder i de enkelte størrelsesgrupper relativt stabil. I Danmark falder andelen af små virksomheder (10-49 årsværk) i kreative erhverv marginalt i løbet af perioden, fra over $7 \%$ i 2007 og 2008 til under $6 \%$ i 2010.

I Sverige er udviklingen den samme, hvor andelen af små virksomheder udgør 2,4 \% i 2007 og kun 1,9\% i 2010.

Andelen mikrovirksomheder er steget i alle fire lande i perioden 20072010 - udviklingen gør sig gældende både i kreative og øvrige erhverv.

\subsection{Beskæftigelse fordelt på virksomhedsstørrelser}

Mikro- (0-9 årsværk) og små virksomheder (10-49 årsværk) i de kreative erhverv står for en større andel af den samlede beskæftigelse ${ }^{7}$ end virksomheder i samme størrelsesgrupper i resten af de markedsmæssige erhverv i alle lande bortset fra Finland, hvor det er de største virksomheder

${ }^{7}$ Beskæftigelsen defineres hér som årsværk. 
med 100+ årsværk, som står for en større andel af beskæftigelsen blandt kreative erhverv end tilsvarende virksomheder i øvrige erhverv.

Figur 9. Andel årsværk $\mathrm{i}$ kreative og øvrige erhverv fordelt efter virksomhedsstørrelse. 2007 og 2010

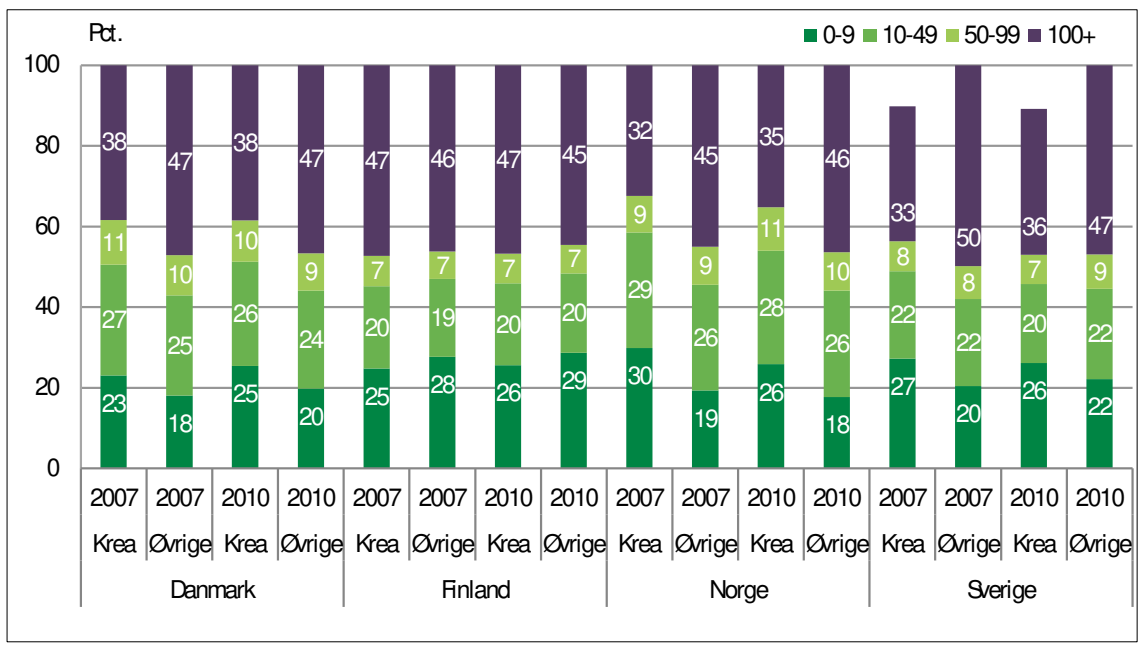

Svenske tal indgår delvis grundet diskretionering.

I Danmark står mikro- og små virksomheder for $51 \%$ af den samlede beskæftigelse i de kreative erhverv, mens virksomheder med tilsvarende størrelse i øvrige erhverv dækker $44 \%$ af beskæftigelsen i samme erhverv i 2010.

Samme tendens gør sig gældende i Norge, hvor de mindste virksomheder dækker over $54 \%$ af den samlede beskæftigelse i de kreative erhverv, mens de mindste virksomheder i øvrige erhverv står for $44 \%$ af den samlede beskæftigelse i disse erhverv.

I Sverige dækker de mindste virksomheder $46 \%$ af den samlede beskæftigelse i kreative erhverv mod en andel på $44 \%$ i øvrige markedsmæssige erhverv.

Det omvendte gælder store virksomheder med 100+ årsværk i de kreative erhverv og øvrige erhverv, hvor disse virksomheder dækker henholdsvis $38 \%$ (kreative) og $47 \%$ (øvrige) af den samlede beskæftigelse i Danmark, $35 \%$ og $46 \%$ i Norge og henholdsvis $36 \%$ (kreative) og $47 \%$ (øvrige) i Sverige i 2010.

I Finland beskæftiger de mindste virksomheder i kreative erhverv 46 $\%$ af alle beskæftigede i disse erhverv; i øvrige erhverv beskæftiger virksomheder af denne størrelse $49 \%$ i 2010. Omvendt er det for store virksomheder med mindst 100 årsværk; disse virksomheder beskæftiger 47 $\%$ af alle beskæftigede i kreative erhverv, mens virksomheder i øvrige 
erhverv med samme størrelse dækker $45 \%$ af beskæftigelsen i disse erhverv i 2010.

\subsection{Beskæftigelse pr. virksomhed fordelt på virksomhedsstørrelser}

Store virksomheder med mindst 100 årsværk er større i øvrige erhverv end tilsvarende virksomheder i kreative erhverv.

I 2010 beskæftiger virksomheder af denne størrelse i gennemsnit 306 årsværk i kreative erhverv og 409 årsværk i øvrige erhverv i Danmark. I Norge har de store virksomheder i øvrige erhverv 339 årsværk i gennemsnit, mens lignende virksomheder i kreative erhverv kun beskæftiger i gennemsnit 240 årsværk. Svenske store virksomheder i øvrige erhverv beskæftiger 453 årsværk, mens virksomheder af samme størrelse i kreative erhverv har i gennemsnit 392 årsværk i 2010.

I Finland er den gennemsnitlige beskæftigelse i de store virksomheder kun marginalt forskellig i kreative og øvrige erhverv.

\subsection{Omsætning fordelt på virksomhedsstørrelser}

Størstedelen af omsætningen i de kreative og øvrige erhverv genereres af de relativt få store virksomheder med 100+ årsværk. I 2010 står disse virksomheder således for henholdsvis $37 \%, 35 \%$ og $40 \%$ af den samlede omsætning i de kreative erhverv i Danmark, Norge og Sverige, mens de finske store virksomheder dækker hele $71 \%$ af den samlede omsætning i den kreative sektor.

Dermed er koncentrationen inden for de kreative erhverv mindre i Danmark, Norge og Sverige sammenlignet med det øvrige erhvervsliv, hvor de store virksomheders omsætning udgør mellem 49 og $56 \%$ af den samlede omsætning i øvrige markedsmæssige erhverv i de tre lande.

I Finland er tendensen anderledes, hvor store virksomheder genererer $56 \%$ af den samlede omsætning i øvrige erhverv, mens de kreative erhvervs virksomheder af samme størrelse som nævnt dækker $71 \%$ 
Figur 10. Andel af omsætning i kreative og øvrige erhverv fordelt efter virksomhedsstørrelse. 2007 og 2010

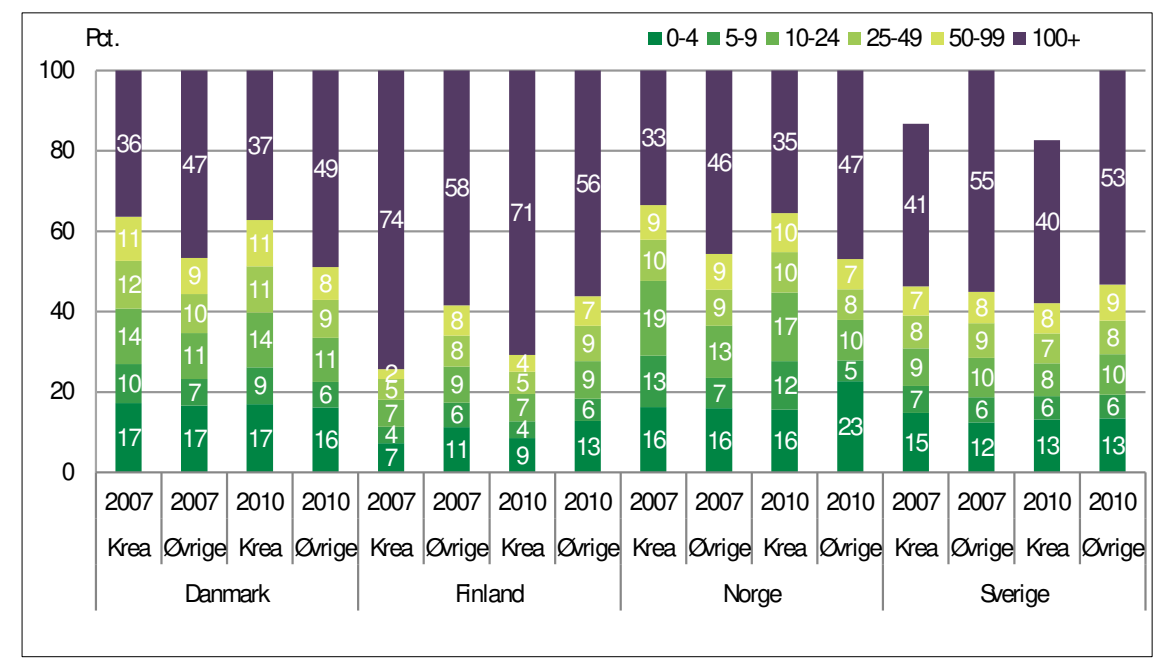

Svenske tal indgår delvis grundet diskretionering.

I 2007 genererede danske mikro- (0-9 årsværk) og små virksomheder med 10-24 årsværk virksomheder relativt større andel af de kreative erhvervs omsætning end tilsvarende virksomheder i øvrige erhverv. De kreative virksomheder stod for henholdsvis $41 \%$ af omsætningen i den kreative industri, hvor virksomheder af samme størrelse kun genererede $35 \%$ af omsætningen i øvrige erhverv.

Det er virksomheder med mindst 5 årsværk i kreative erhverv, der genererer mere omsætning end tilsvarende virksomheder i øvrige erhverv.

Udviklingen fortsætter igennem hele perioden og i 2010 står de kreative virksomheder i de mindste størrelsesgrupper for henholdsvis $17 \%$, $9 \%$ og $14 \%$, mens virksomhederne med samme størrelse i øvrige erhverv genererer en mindre andel af den samlede omsætning i disse erhverv, henholdsvis $16 \%, 6 \%$ og $11 \%$

Norske kreative virksomheder skaber mere omsætning end tilsvarende virksomheder i øvrige erhverv i størrelsesgrupperne 5-9 årsværk og 10-24 årsværk. I 2007 skaber disse virksomheder således henholdsvis $13 \%$ og $19 \%$ af den samlede omsætning i de kreative erhverv, mens tilsvarende virksomheder i øvrige erhverv kun står bag henholdsvis $7 \%$ og $13 \%$ i 2007. Udviklingen er ensartet til 2010, hvor de kreative små og mellemstore virksomheder genererer $12 \%$ og $17 \%$ i modsætning til virksomheder i øvrige erhverv i samme størrelsesgruppe, som står bag 5 $\%$ og $10 \%$ af omsætningen. 


\section{Produktivitet i kreative erhverv}

I denne rapport anvendes to mål for produktivitet; omsætning pr. årsværk og værditilvækst pr. årsværk.

Omsætning pr. årsværk tager ikke højde for de omkostninger, som virksomheden har i forbindelse med skabelse af omsætning. Dette tal anvendes i rapporten, idet oplysningerne findes for alle fire lande.

Værditilvækst pr. årsværk er et mere validt mål for produktivitet, idet der heri tages højde for virksomhedens omkostninger i forbindelse med skabelse af merværdi, såsom lønomkostninger.

Oplysning om værditilvækst findes kun for Danmark, Sverige og Norge.

\subsection{Omsætning pr. ansat}

I Danmark og Norge genererer virksomheder i de kreative erhverv mindre omsætning pr. ansat ${ }^{8}$ end en gennemsnitlig virksomhed i 2010. I Finland og Sverige skaber de kreative erhverv derimod mere omsætning pr. ansat end virksomheder i andre markedsmæssige erhverv.

Alle kreative erhvervsgrupper skaber mindre omsætning pr. årsværk end øvrige erhverv undtaget Film og video, IT (hardware og engroshandel), Mode samt Telekommunikationsudstyr, radio og TV.

${ }^{8}$ Ansatte defineres hér som årsværk. 
Figur 11. Omsætning pr. årsværk i kreative og øvrige erhverv. 2010

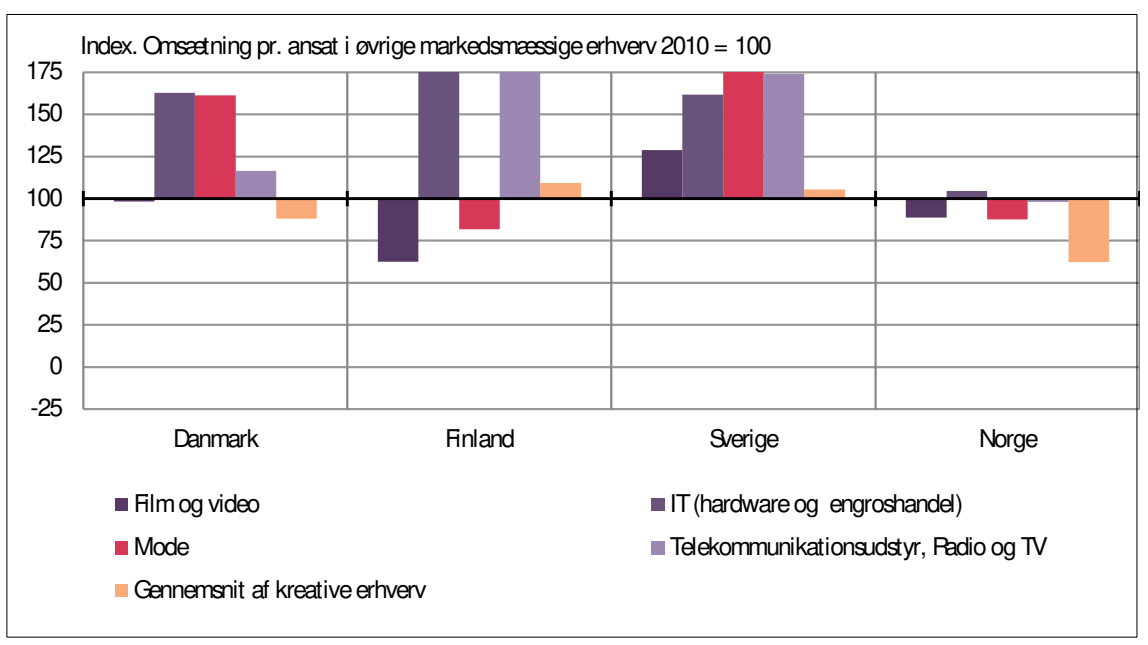

I Finland skaber IT (hardware og engroshandel) $153 \%$ mere omsætning pr. ansat og Telekommunikationsudstyr, radio og TV $348 \%$ mere omsætning pr. ansat end gennemsnittet af øvrige markedsmæssige erhverv i 2010.

I Sverige skaber erhvervet Mode $195 \%$ mere omsætning pr. ansat end gennemsnittet af markedsmæssige erhverv i 2010. I Danmark skaber disse erhverv ligeledes mere omsætning pr. ansat end gennemsnittet (over $60 \%$ ), mens det i Norge kun er IT (hardware og engroshandel), som genererer mere omsætning pr. ansat end gennemsnittet med $5 \%$ i 2010.

Kunst og kunsthåndværk og Arkitektur er de to kreative erhverv, hvor omsætningen pr. ansat er lavest. I Danmark genererer virksomhederne i Kunst og kunsthåndværk mellem 27 og $28 \%$ af den gennemsnitlige omsætning pr. ansat i landets øvrige virksomheder i perioden 2007-2010, tilsvarende Finland, hvor erhvervets andel ligger på 28-40 \% af omsætning pr. ansat i øvrige erhverv i perioden.

Omsætning pr. ansat i svenske arkitekturvirksomheder svarer til blot 36-40 \%, mens lignende virksomheder i Norge skaber 31-43\% af gennemsnitsomsætningen i øvrige erhverv i årene 2007 til 2010. 


\subsection{Omsætning pr. ansat fordelt på virksomhedsstørrelser}

Virksomheder i kreative erhverv genererer gennemsnitligt mindre omsætning pr. ansat end virksomheder i øvrige erhverv i Danmark og Norge.

Tabel 11. Omsætning pr. årsværk i kreative og øvrige erhverv fordelt efter virksomhedsstørrelse. 2007 og 2010

\begin{tabular}{|c|c|c|c|c|c|c|c|c|}
\hline & \multicolumn{8}{|c|}{ Omsætning pr. ansat, landets egen valuta } \\
\hline & \multicolumn{2}{|c|}{ Danmark } & \multicolumn{2}{|c|}{ Finland } & \multicolumn{2}{|c|}{ Norge } & \multicolumn{2}{|c|}{ Sverige } \\
\hline & $\begin{array}{l}\text { Kreative } \\
\text { erhverv }\end{array}$ & $\begin{array}{r}\emptyset \text { vrige } \\
\text { erhverv }\end{array}$ & $\begin{array}{c}\text { Kreative } \\
\text { erhverv }\end{array}$ & $\begin{array}{r}\emptyset \text { vrige } \\
\text { erhverv }\end{array}$ & $\begin{array}{r}\text { Kreative } \\
\text { erhverv }\end{array}$ & $\begin{array}{r}\emptyset \text { vrige } \\
\text { erhverv }\end{array}$ & $\begin{array}{c}\text { Kreative } \\
\text { erhverv }\end{array}$ & $\begin{array}{l}\varnothing \text { vrige } \\
\text { erhverv }\end{array}$ \\
\hline \multicolumn{9}{|l|}{2007 Mikro } \\
\hline 0-4 årsværk & 2.937 & 4.186 & 157 & 136 & 2.543 & 5.197 & $\ldots$ & 3.084 \\
\hline 5-9 årsværk & 1.746 & 1.711 & 176 & 178 & 2.196 & 2.327 & $\ldots$ & 2.036 \\
\hline \multicolumn{9}{|l|}{ Små } \\
\hline 10-24 årsværk & 1.805 & 1.870 & 214 & 190 & 2.506 & 2.587 & $\ldots$ & 2.291 \\
\hline 25-49 årsværk & 1.964 & 2.088 & 197 & 222 & 2.401 & 2.587 & $\ldots$ & 2.668 \\
\hline \multicolumn{9}{|l|}{ Mellemstore } \\
\hline 50-99 årsværk & 2.006 & 2.108 & 118 & 261 & 2.327 & 2.896 & $\ldots$ & 2.765 \\
\hline \multicolumn{9}{|l|}{ Store } \\
\hline 100+ årsværk & 1.906 & 2.288 & 560 & 298 & 2.525 & 3.122 & $\ldots$ & 3.184 \\
\hline Alle & 2.061 & 2.375 & 237 & 214 & 2.416 & 3.119 & $\ldots$ & 2.671 \\
\hline \multicolumn{9}{|l|}{2010 Mikro } \\
\hline 0-4 årsværk & 2.571 & 3.845 & 163 & 149 & 2.733 & 11.586 & $\ldots$ & 3.139 \\
\hline 5-9 årsværk & 1.694 & 1.720 & 168 & 158 & 2.142 & 2.312 & $\ldots$ & 1.865 \\
\hline \multicolumn{9}{|l|}{ Små } \\
\hline 10-24 årsværk & 1.983 & 1.955 & 200 & 193 & 2.260 & 2.742 & $\ldots$ & 2.301 \\
\hline 25-49 årsværk & 2.143 & 2.274 & 202 & 250 & 2.077 & 2.990 & $\ldots$ & 2.656 \\
\hline \multicolumn{9}{|l|}{ Mellemstore } \\
\hline 50-99 årsværk & 2.374 & 2.197 & 186 & 245 & 2.043 & 3.328 & $\ldots$ & 3.146 \\
\hline \multicolumn{9}{|l|}{ Store } \\
\hline 100+ årsværk & 2.047 & 2.620 & 502 & 297 & 2.287 & 4.285 & $\ldots$ & 3.384 \\
\hline Alle & 2.135 & 2.435 & 237 & 215 & 2.257 & 4.540 & $\ldots$ & 2.748 \\
\hline
\end{tabular}

I 2010 Danmark genererer små (10-24 årsværk) og mellemstore virksomheder i kreative erhverv henholdsvis $1 \%$ og $8 \%$ mere omsætning pr. ansat end tilsvarende virksomheder i øvrige erhverv. Samme tendens gør sig gældende i 2009. I årene 2007-2008 havde mikrovirksomheder i kreative erhverv med 5-9 årsværk samme eller marginalt højere gennemsnitlig omsætning pr. ansat end virksomheder i øvrige erhverv.

I Finland er det særligt mikro-, virksomheder med 10-24 årsværk samt store virksomheder, som har mere omsætning pr. ansat end virksomheder af samme størrelse i øvrige erhverv i 2010. I 2007 og 2008 var det endvidere små virksomheder i kreative erhverv, som havde mere omsætning pr. ansat end virksomheder i øvrige markedsmæssige erhverv i Finland. 
I Norge genererer alle størrelser af virksomheder i kreative erhverv mindre omsætning pr. ansat end tilsvarende virksomheder i øvrige erhverv i 2008-2010. På grund af diskretionering af data omhandlende kreative erhverv fordelt på virksomhedsstørrelse i den svenske statistik er det ikke muligt at lave en tilsvarende beregning for Sverige.

Figur 12. Omsætning pr. ansat i kreative og øvrige erhverv fordelt efter virksomhedsstørrelse. 2010

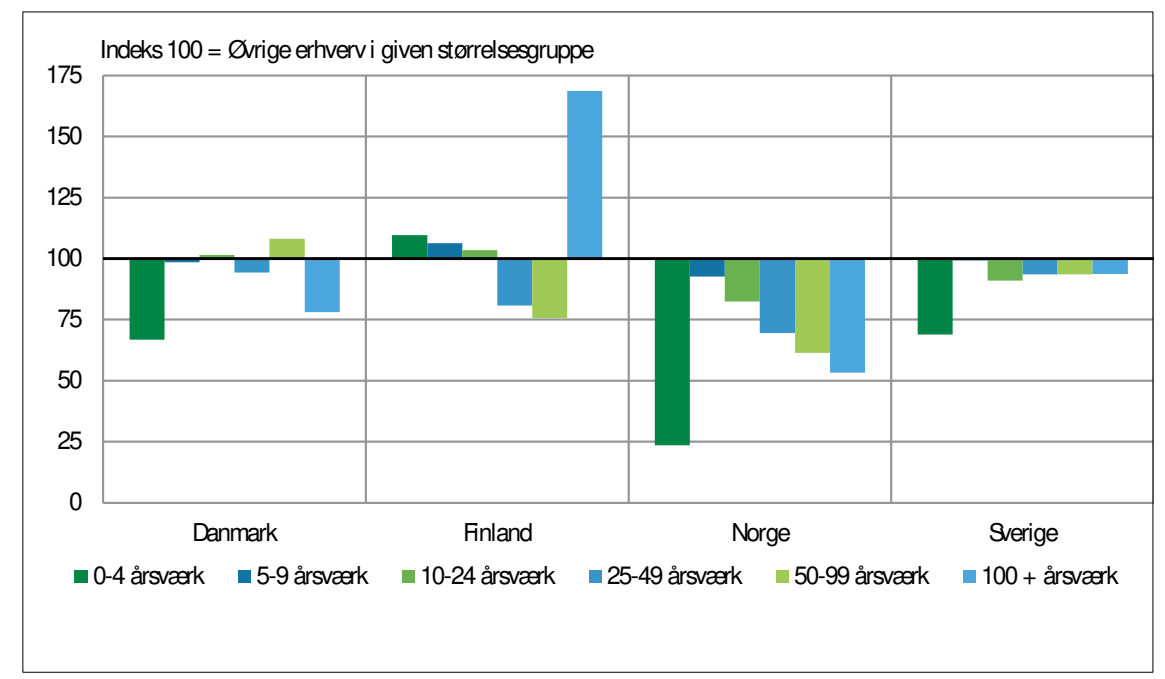

\subsection{Værditilvækst i kreative erhverv}

Analysen af værditilvækst baserer sig udelukkende på data fra Danmark, Sverige og Norge - det har ikke været muligt at indhente oplysninger om værditilvækst fra det finske statistikkontor.

I årene 2007-2010 udgør værditilvæksten i de kreative erhverv i Norden mellem 6,4 \% (Norge 2008) og $15 \%$ (Sverige 2008) af værditilvæksten i de ikke-finansielle markedsmæssige erhverv i landene.

I Danmark udgør værditilvæksten i kreative virksomheder ca. $13 \%$ af den samlede værditilvækst, mens tallet i Sverige ligger omkring $15 \%$ og i Norge på mellem $6 \%$ og $11 \%$ i samme periode.

Det kreative erhverv IT (programmering og services) står for størstedelen af værditilvæksten blandt de kreative erhverv med 3,5 \% af den samlede værditilvækst i Danmark, 4 \% i Sverige og 2, 1 \% i Norge i 2010.

Detail genererer den anden største andel af værditilvæksten i Danmark og Norge igennem hele perioden 2007-2010, mens det i Sverige er Telekommunikationsudstyr, radio og TV, som tegner sig for den anden- 
største andel af den samlede værditilvækst i landets markedsmæssige erhverv, stærkt efterfulgt af Bøger og presse i alle tre lande.

De kreative erhverv IT (programmering og services) og Bøger og presse skaber forholdsmæssigt mere værditilvækst end omsætning i alle fire lande; i Danmark udgør omsætningen i IT (programmering og services) $2 \%$ i 2010, mens værditilvæksten udgør 3,5 \% af den samlede værditilvækst i de markedsmæssige erhverv. Tilsvarende er omsætningsandelen $2,3 \%$ og værditilvækstandelen $4 \%$ i Sverige og henholdsvis $1,2 \%$ og 2,1 \% i Norge i 2010 .

Det kreative erhverv Bøger og presse repræsenteres også i det kreative erhverv Detail, hvori brancherne "Detailhandel med aviser og papirvarer" og "Detailhandel med bøger" indgår.

Erhvervene Detail og Telekommunikationsudstyr, radio og TV står derimod for større omsætningsandel end værditilvækstandel.

I Danmark var omsætningsandelen i Detail således 2,7 \%, mens værditilvækstandelen i samme erhverv kun udgjorde 2,2 \% i 2010. I Sverige og Norge var andelene 2,7 henholdsvis 2,0 \% af den samlede omsætning og 2,4 henholdsvis 1,6 \% af den samlede værditilvækst i 2010.

\begin{tabular}{|c|c|c|c|c|c|c|c|c|}
\hline \multirow[b]{3}{*}{$\varnothing$ vrige erhverv } & \multicolumn{2}{|c|}{ Danmark } & \multicolumn{2}{|c|}{ Finland } & \multicolumn{2}{|c|}{ Sverige } & \multicolumn{2}{|c|}{ Norge } \\
\hline & \multicolumn{2}{|c|}{$\begin{array}{l}\text { Værdi- Omsæt- } \\
\text { tilvækst ningsandel }\end{array}$} & $\begin{array}{l}\text { Værdi- } \\
\text { tilvækst n }\end{array}$ & $\begin{array}{l}\text { Omsæt- } \\
\text { ngsandel }\end{array}$ & \multicolumn{2}{|c|}{$\begin{array}{l}\text { Værdi- Omsæt- } \\
\text { tilvækst ningsandel }\end{array}$} & \multicolumn{2}{|c|}{$\begin{array}{l}\text { Værdi- Omsæt- } \\
\text { tilvækst ningsandel }\end{array}$} \\
\hline & 87,0 & 87,4 & $\ldots$ & 84,3 & 85,1 & 85,8 & 92,7 & 92,7 \\
\hline Kreative erhverv & 13,0 & 12,6 & $\ldots$ & 15,7 & 14,9 & 14,2 & 7,3 & 7,3 \\
\hline \multicolumn{9}{|l|}{ Heraf: } \\
\hline Arkitektur & 0,4 & 0,2 & $\ldots$ & 0,1 & 0,2 & 0,1 & 0,2 & 0,1 \\
\hline Bøger og presse & 1,8 & 1,7 & $\ldots$ & 1,6 & 1,7 & 1,7 & 1,4 & 1,4 \\
\hline Design & 0,2 & 0,2 & $\ldots$ & 0,0 & 0,3 & 0,2 & 0,1 & 0,1 \\
\hline Detail & 2,2 & 2,7 & $\ldots$ & 1,7 & 2,4 & 2,7 & 1,6 & 2,0 \\
\hline Film og video & 0,3 & 0,2 & $\ldots$ & 0,1 & 0,3 & 0,3 & 0,1 & 0,1 \\
\hline \multicolumn{9}{|l|}{ IT (hardware og engros- } \\
\hline handel) & 0,8 & 1,3 & $\ldots$ & 0,8 & 0,6 & 1,0 & 0,4 & 0,7 \\
\hline \multicolumn{9}{|l|}{ IT (programmering og } \\
\hline services) & 3,5 & 2,0 & $\ldots$ & 1,3 & 4,0 & 2,3 & 2,1 & 1,2 \\
\hline Kunst og kunsthåndværk & $\ldots$ & 0,1 & $\ldots$ & 0,1 & 0,3 & 0,2 & 0,0 & 0,0 \\
\hline Mode & 1,5 & 1,9 & $\ldots$ & 0,4 & 1,1 & 1,6 & 0,3 & 0,5 \\
\hline Musik & 0,1 & 0,0 & $\ldots$ & 0,0 & 0,1 & 0,1 & 0,0 & 0,0 \\
\hline Møbler og interiør & 0,8 & 0,9 & $\ldots$ & 0,4 & 0,5 & 0,5 & 0,4 & 0,4 \\
\hline \multicolumn{9}{|l|}{ Telekommunikationsud- } \\
\hline styr, radio og TV & 0,9 & 0,9 & $\ldots$ & 8,7 & 2,7 & 3,1 & 0,5 & 0,8 \\
\hline Reklame & 0,6 & 0,5 & $\ldots$ & 0,4 & 0,6 & 0,5 & 0,2 & 0,2 \\
\hline
\end{tabular}

Oplysninger om værditilvækst findes ikke for Finland.

${ }^{9}$ Oplysninger om værditilvækst findes ikke for Finland. 


\subsubsection{Værditilvækst pr. ansat}

Samlet set genererer de kreative erhverv mindre værditilvækst pr. virksomhed end virksomheder i øvrige markedsmæssige erhverv. Sammenholder man værditilvæksten med antal ansatte, ${ }^{10}$ fremgår det dog, at udvalgte kreative erhverv skaber mere værditilvækst pr. ansat end øvrige markedsmæssige erhverv i Danmark, Norge og Sverige ${ }^{11 .}$

I Danmark er gennemsnitlig værditilvækst pr. ansat i kreative virksomheder i Danmark på mellem 82 og $91 \%$ af værditilvæksten pr. ansat i øvrige erhverv i perioden 2007-2010. Norske virksomheder i kreative erhverv genererer mellem 52 og $91 \%$ af værditilvæksten pr. ansat i ørige erhverv i Norge i løbet af samme periode.

I 2010 skaber virksomheder i kreative erhverv i Danmark værditilvækst pr. ansat svarende til $88,5 \%$ af værditilvækst pr. ansat i øvrige erhverv. Tilsvarende tal for Norge er 59,2\%

Svenske virksomheder i kreative erhverv genererer samlet set mellem 1 og $11 \%$ mere værditilvækst pr. ansat end virksomheder i øvrige erhverv igennem hele perioden 2007-2010. I 2010 skabes der 6,8 \% mere værditilvækst pr. ansat i kreative virksomheder end virksomheder i øvrige erhverv i landet.

I 2010 genererer 3 af de 13 kreative erhverv i Danmark og 7 i Sverige højere gennemsnitlig værditilvækst pr. ansat end øvrige erhverv. Denne tendens er gennemgående i årene 2007-2010.

I Norge er skaber virksomheder i kreative erhverv lavere værditilvækst pr. ansat end virksomheder i øvrige erhverv i perioden 2008-2010, mens der i 2007 var 6 kreative erhverv, som skabte mere værditilvækst pr. ansat end øvrige erhverv. Dette er dog et resultat af udviklingen i øvrige erhverv snarere end udviklingen i de kreative erhverv i landet.

\footnotetext{
${ }^{10}$ Ansatte omregnet til årsværk.

11 Oplysninger om værditilvækst findes ikke for Finland.
} 
Figur 13. Værditilvækst pr, ansat i kreative og øvrige erhverv. 2010

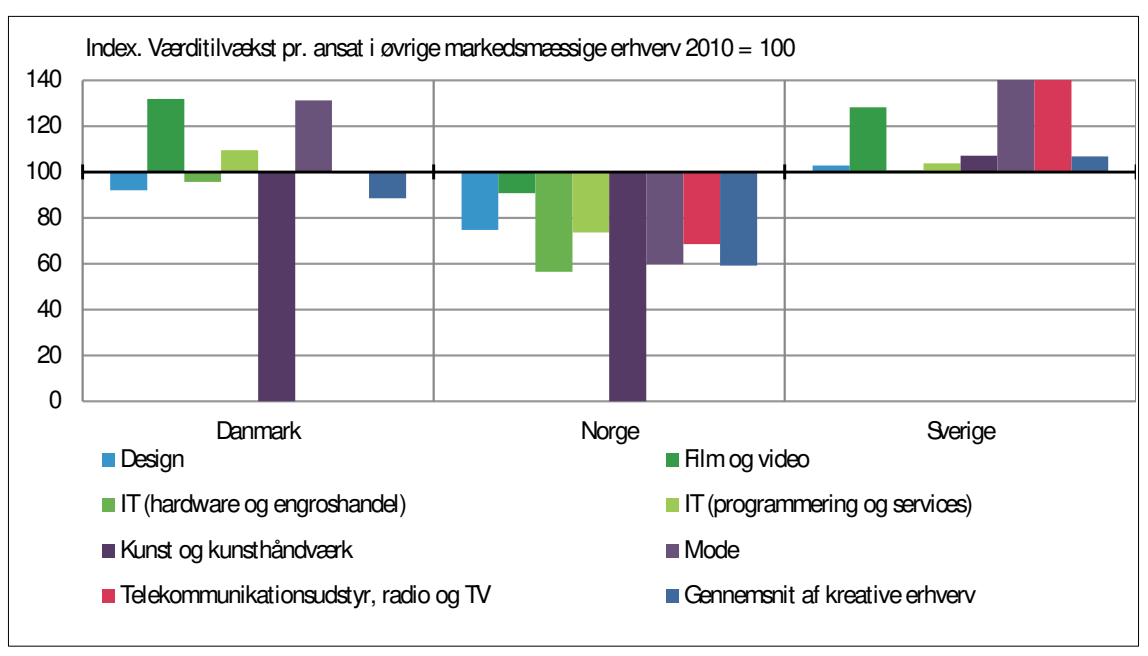

Oplysninger om værditilvækst findes ikke for Finland. I Sverige genererer Mode og Telekommunikationsudstyr, radio og TV værditilvækst pr. ansat svarende til index 207 og 155 i 2010.

De tre kreative erhverv med højere værditilvækst pr. ansat end øvrige erhverv er i Danmark Film og video (31,9\% højere end øvrige erhverv), Mode (31,1 \% højere end øvrige erhverv og IT (programmering og services) (9,5\% højere end øvrige erhverv) i 2010.

Svenske kreative erhverv står samlet set for 6,8 \% højere andel af værditilvækst pr. ansat end øvrige erhverv i 2010. Det er virksomheder i tre kreative erhverv, som hovedsageligt medvirker til dette: Mode (107,3 \% højere værditilvækst pr. ansat end øvrige erhverv), Telekommunikationsudstyr, radio og TV (55,3\% højere) og Film og video (28,1 \% højere).

Herudover genererer Design, IT (hardware og engroshandel), IT (programmering og services) og Kunst og kunsthåndværk mellem 0,7-7 \% højere værditilvækst pr. ansat end gennemsnittet blandt øvrige erhverv i Sverige i 2010.

Tabel 13. Værditilvækst pr. ansat fordelt på erhverv. 2010

\begin{tabular}{|c|c|c|c|}
\hline & \multicolumn{3}{|c|}{ Værditilvækst pr. ansat, landets egen valuta } \\
\hline & Danmark & Sverige & Norge \\
\hline Alle erhverv & 695 & 811 & 1.298 \\
\hline$\varnothing$ vrige erhverv & 708 & 811 & 1.367 \\
\hline Arkitektur & 609 & 693 & 873 \\
\hline Bøger og presse & 592 & 683 & 842 \\
\hline Design & 651 & 833 & 1.023 \\
\hline Detail & 423 & 558 & 549 \\
\hline Film og video & 933 & 1.039 & 1.241 \\
\hline IT (hardware og salg) & 677 & 817 & 772 \\
\hline IT (programmering og services) & 775 & 842 & 1.006 \\
\hline Kunst og kunsthåndværk ${ }^{1}$ & $\ldots$ & 869 & $\ldots$ \\
\hline Mode & 928 & 1.681 & 819 \\
\hline
\end{tabular}




\begin{tabular}{lcrr} 
& Værditilvækst pr. ansat, landets egen valuta & Norge \\
& Danmark & Sverige & 953 \\
Musik & 653 & 733 & 684 \\
Møbler og interiør & 574 & 591 & 937 \\
Telekommunikationsudstyr, radio og TV & 704 & 1.259 & 824 \\
Reklame & 627 & 662 & 809 \\
Kreative i alt, gennemsnit & 627 & 866 & \\
\hline
\end{tabular}

${ }^{1}$ Værditilvækst opgøres ikke for branchen Kunst og kunsthåndværk i Danmark og Norge.

Norske $^{12}$ virksomheder i Arkitektur, Design, Film og video, IT (hardware og engroshandel), IT (programmering og services) og Telekommunikationsudstyr, radio og TV genererede højere værditilvækst pr. ansat end øvrige erhverv i 2007.

I perioden 2007-2010 har værditilvæksten pr. ansat dog været faldende i kreative erhverv sammenlignet med øvrige erhverv i Norge. I 2010 er den gennemsnitlige værditilvækst pr. ansat i kreative erhverv knap $41 \%$ lavere end i øvrige erhverv i Norge.

Til sammenligning er den samlede værditilvækst i de kreative erhverv i Norge faldet fra $11 \%$ af den samlede værditilvækst i landets virksomheder i 2007 til blot $7 \%$ i 2010.

\subsubsection{Værditilvækst pr. ansat fordelt på virksomhedsstørrelser}

I Danmark og Sverige skaber virksomheder i kreative erhverv generelt lavere værditilvækst pr. ansat end tilsvarende virksomheder i øvrige erhverv. Det er særligt virksomheder med 0-4 ansatte, hvor værditilvæksten pr. ansat udgør under halvdelen af den værditilvækst pr. ansat, som skabes i virksomheder af sammes størrelse i øvrige erhverv.

I Norge er det særligt kreative virksomheder i størrelsesgrupperne 0-4 ansatte og mindst 100 ansatte, som genererer markant lavere værditilvækst pr. ansat end lignende virksomheder i øvrige erhverv.

Næsten alle størrelser af virksomheder i Sveriges kreative erhverv skaber højere værditilvækst pr. ansat end virksomheder af tilsvarende størrelse i øvrige erhverv i 2009 og 2010. Dette gælder virksomheder med mindst 5 ansatte. I 2007 og 2008 gælder dette virksomheder med mindst 10 ansatte.

12 Statistikken indeholder ikke oplysninger om værditilvækst i branchen Kunst og kunsthåndværk i Norge. 
I Norge skaber virksomheder med 10-24 ansatte mere værditilvækst pr. ansat i perioden 2007-2010.

Figur 14. Værditilvækst pr. årsværk i kreative erhverv fordelt på virksomhedsstørrelse, 2007 og 2010

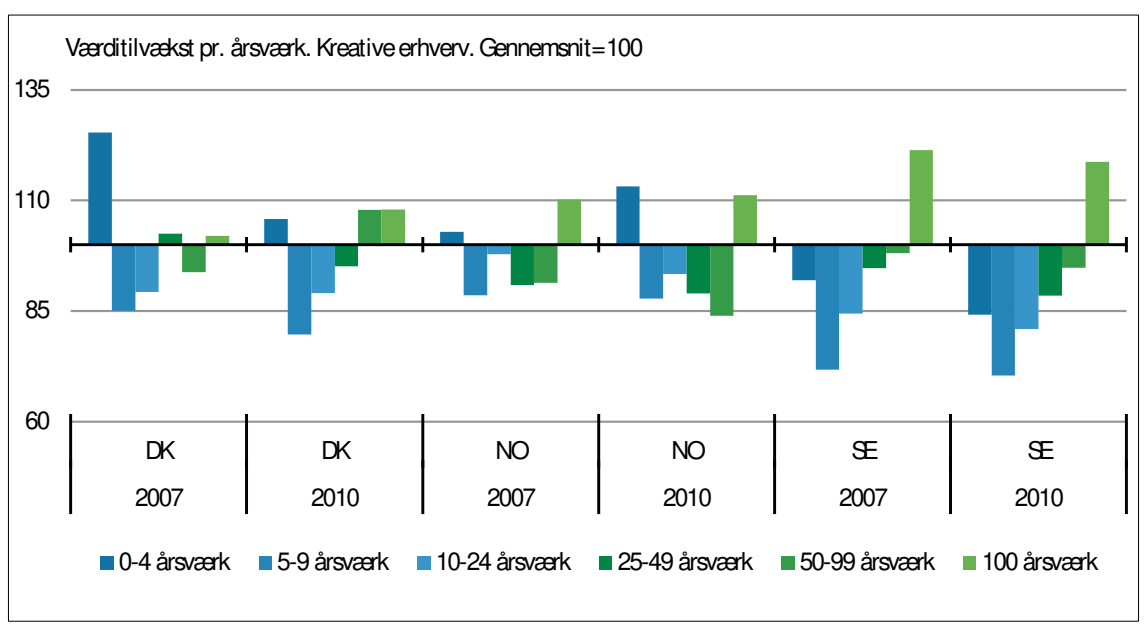

I 2007 skabte de mindste virksomheder i Danmark højere værditilvækst pr. ansat end gennemsnittet for alle kreative virksomheder, mens det $\mathrm{i}$ 2010 er virksomheder med mindst 50 ansatte, som skaber mere værditilvækst pr. ansat end gennemsnittet.

Norske kreative virksomheder med mindst 100 ansatte skabte i 2007 højere værditilvækst pr. ansat end en gennemsnitlig virksomhed i kreative erhverv, mens det i 2010 er virksomheder med henholdsvis 0-4 ansatte og over 100 ansatte, der ligger over gennemsnittet. I Sverige er det virksomheder med mindst 100 ansatte, som skaber gennemsnitligt mere værditilvækst pr. ansat i hele perioden 2007-2010. 



\section{Summary}

The cultural and creative industries in Denmark, Norway, and Sweden appear to be less affected by the financial crisis than other industries in the Nordic countries. The creative industries' share of the total number of employed has grown by $2 \%$ in Sweden and $10 \%$ in Norway during 20072010. Meanwhile, employment in other market related industries has fallen by $1 \%$ in Sweden and grown by $7 \%$ in Norway.

Employment in the creative industries has fallen by almost $13 \%$ in Danish creative industries during 2007-2010, while the decrease in other industries has reached 14\%. In Finland, employment in the creative industries has fallen by $5 \%$ during 2007-2010, while employment in other industries has fallen by $2 \%$ during the same time.

\begin{tabular}{|c|c|c|c|c|}
\hline & FTEs & Turnover & $\begin{array}{l}\text { Value growth } \\
\text { (value added) }\end{array}$ & Number of firms \\
\hline \multicolumn{5}{|l|}{ Denmark } \\
\hline Creative industries & $\div$ & $\div$ & $\div$ & + \\
\hline Other industries & $\div$ & $\div$ & $\div$ & $\div$ \\
\hline \multicolumn{5}{|l|}{ Finland } \\
\hline Creative industries & $\div$ & $\div$ & $\ldots$ & + \\
\hline Other industries & $\div$ & $\div$ & $\ldots$ & + \\
\hline \multicolumn{5}{|l|}{ Norway } \\
\hline Creative industries & + & + & + & + \\
\hline Other industries & + & + & + & + \\
\hline \multicolumn{5}{|l|}{ Sweden } \\
\hline Creative industries & + & + & + & + \\
\hline Other industries & $\div$ & + & + & + \\
\hline
\end{tabular}

The creative industries in the four Nordic countries of Denmark, Finland, Norway, and Sweden, employ a little over 795,300 FTEs (full-time equivalent workers) in 2010. The creative industries thereby account for $13 \%$ of the total number of employed in market related industries in the four countries.

The creative industries have different sizes in the Nordic countries. In Denmark and Sweden, the creative industries account for $15 \%$ of the total number of employed, while in Finland, they cover over $11 \%$ and in Norway $12 \%$ of employment in 2010. 
Figure A. Share of FTEs in creative and other industries. 2007 and 2010

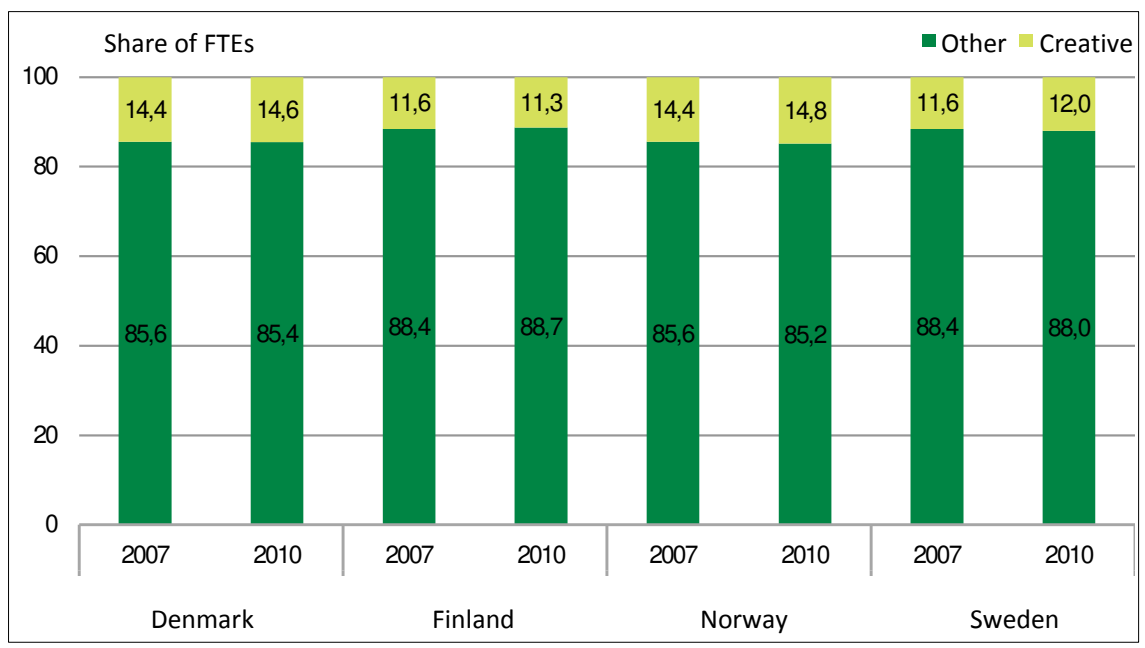

The structure of creative industries is different in the Nordic countries. In Denmark and Norway, Retail is the largest industry group with $4 \%$ of the total number of employed, while IT (programming and services) is the largest group with $2 \%$ and $4 \%$ of total employment in market related industries in Finland and Sweden, respectively.

Firms in the creative industries had a turnover of 360 billion Danish kroner in Denmark (equivalent to $13 \%$ of the country's total turnover and approximately 48 billion EUR ${ }^{13}$ ), 56 billion EUR in Finland (equivalent to $16 \%$ of total turnover), 331 billion Norwegian kroner in Norway (equivalent to 7\% of total turnover and approximately 40 billion EUR), and 929 billion Swedish kronor in Sweden (equivalent to 14\% of total turnover and 108 billion EUR) in 2010.

The creative industries in Denmark and Norway have a stable share of the turnover during 2007-2010. In Finland and Sweden, the share of total turnover in market related industries falls. The trend in Finland is caused by development within Telecommunications, radio and $T V$, which account for a significant share of the creative industries in Finland.

13 The currency exchange rate used is the average for the year 2010. Source: Danmarks Nationalbank. 
Figure B. Share of turnover in creative and other industries. 2007 and 2010

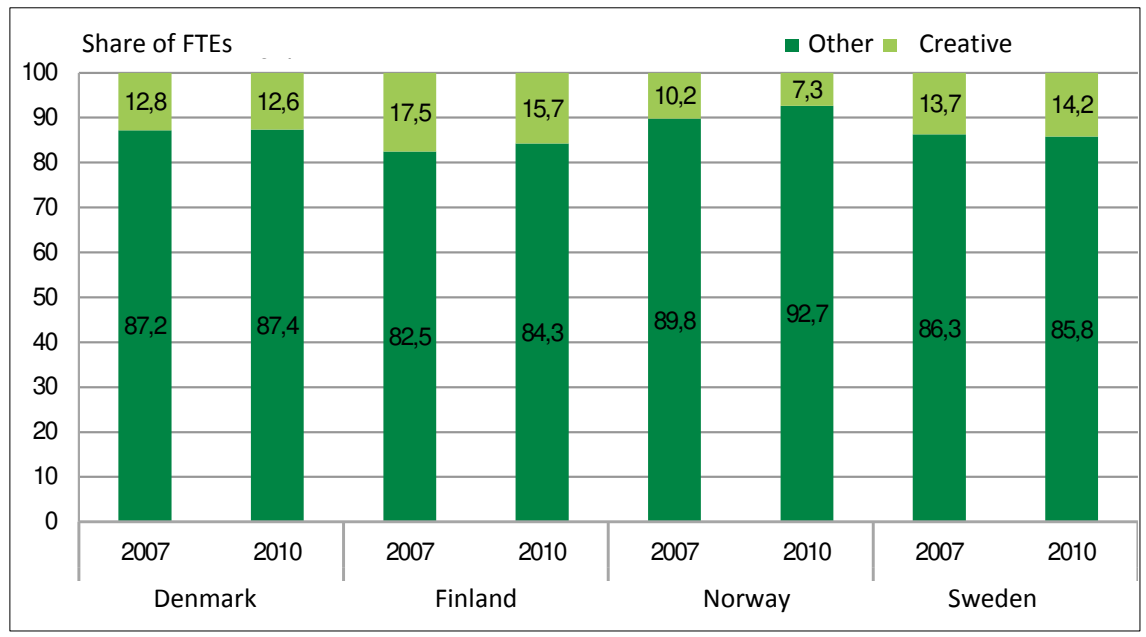

The creative industries have a smaller turnover per employee than firms in other industries in Denmark and Norway. On the other hand, in Sweden and Finland, firms from the creative industries create a higher turnover per employee than firms in other industries. It is especially IT (hardware and wholesale), Telecommunications, radio and TV, Film and video and Fashion, which create more turnover per employee than other industries.

In 2010, turnover per employee in creative industries account for almost 2.2 million Danish kroner in Denmark, while Norwegian creative industries account for little over 2 million Norwegian kroner per employee. Finnish creative industries have a turnover per employee of 258,000 EUR in 2010. The creative industries in Sweden generate little over 3.1 million Swedish kronor per employee in the same year.

It is especially the industry groups of Telecommunications, radio and TV, Fashion, IT (hardware and wholesale) as well as Film and video, which generate a higher turnover per employee than other industries.

In Denmark, IT (hardware and wholesale) and Fashion generate over $60 \%$ higher turnover per employee than other industries in 2010. In Finland, a $150 \%$ higher turnover is generated in IT (hardware and wholesale) than in other industries in 2010, while the same industry group in Sweden creates over $60 \%$ higher turnover per employee than other industries. The industry group Fashion generates almost a $200 \%$ higher turnover per employee than the average for other industries. In Norway, the turnover per employee in IT (hardware and wholesale) is $5 \%$ higher than the average for other industries.

Telecommunications, radio and TV generate almost 350\% higher turnover per employee than other industries in Finland in 2010, while in Sweden, the group generates almost $75 \%$ more per employee. In Den- 
mark, this group has over $15 \%$ higher turnover than the average for other industries in 2010.

Film and video, Fashion, and Telecommunications, radio and TV generate significantly more value growth per employee than firms from other industries. In Denmark, Film and video and Fashion generate over 30\% higher value growth per employee than other industries in 2010, while Fashion in Sweden has a value growth per employee that is $100 \%$ higher than other industries and almost 30\% higher than Film and video.

Telecommunications, radio and TV create over $50 \%$ higher value growth per employee than other industries in Sweden in 2010.

In Denmark and Sweden, firms from the creative industries get more productive than other firms during 2007-2010. Value growth per employee grows during the time by $20 \%$ among creative industries, while other industries only grow by $10 \%$ in Denmark. The corresponding development in Sweden is a $12 \%$ increase for creative industries, with value growth per employee only growing by $6 \%$ in other industries during the same time. In Norway, value growth per employee grows by $9 \%$ in creative industries from 2007 to 2010, while the increase for other industries is $67 \%$ during the same time. ${ }^{14}$

Figure C. Development in value growth per employee in creative industries. 2007-2010

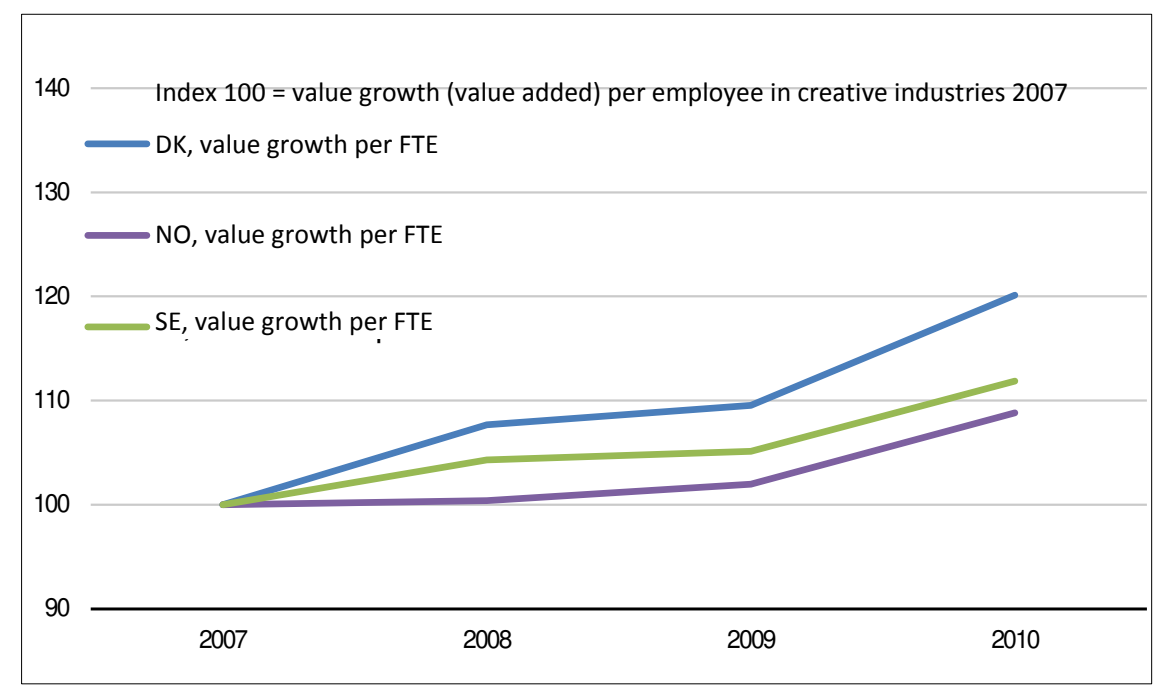

14 Information about value growth was not available for Finland. 
The number of firms in creative industries in the Nordic countries has been relatively stable during 2007-2010. The share of creative firms is highest in Sweden with over $25 \%$ of all active firms (almost 170,000) and lowest in Finland with almost 11\% $(33,000)$.

Figure D. Share of creative and other firms. 2007 and 2010

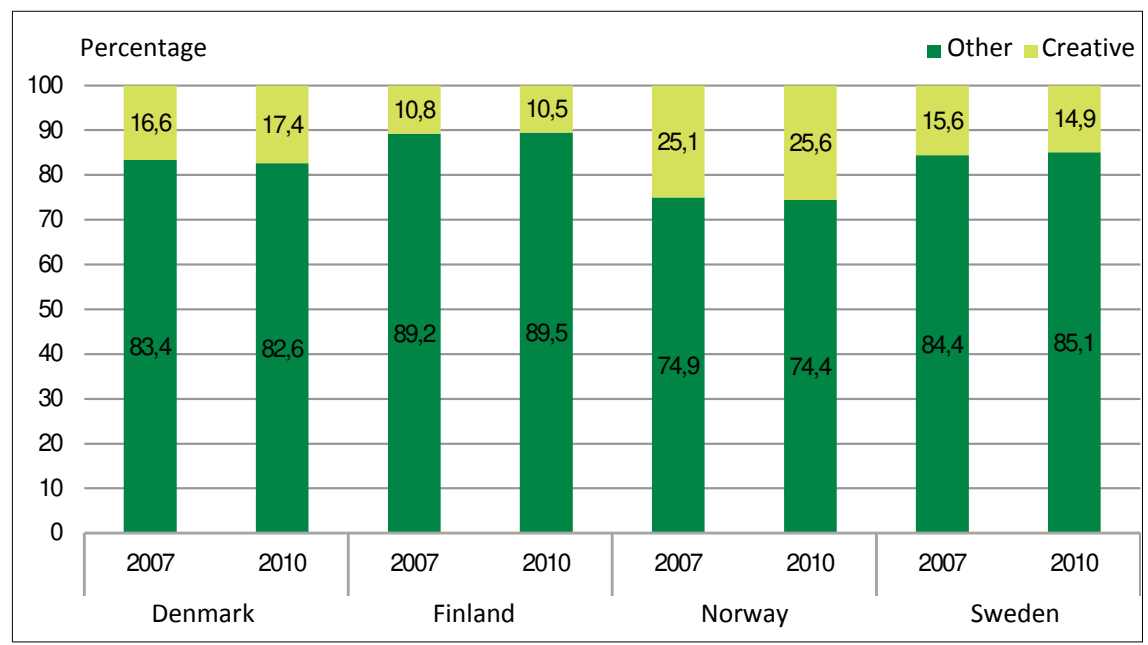

The creative industry with the largest share of firms during 2007-2010 was Retail in Denmark (approximately 5\%), Norway (approximately 4\%), and Finland (approximately 3\%). In Sweden, the largest creative industry is IT (programming and services), which accounts for over $5 \%$ of all active firms in market related industries during 2007-2010.

IT (programming and services) is the second largest creative industry in Denmark during the years 2007-2010, making up around 3\% of the country's firms. The same is found in Norway during those years (almost 3\%).

In Finland Books and press and IT (programming and services) are equally as large and account for $1.4 \%$ of the country's firms, which makes them the second largest creative industries in 2007 and 2008, while IT (programming and services) grow to be the second largest creative industry in 2009. In 2010, IT (programming and services) account for $1.5 \%$ of the firms in Finland.

The largest share of turnover in the creative industries is generated by the relatively few, large corporations with at least 100 FTEs. In Finland, firms of this magnitude account for $71 \%$ of the total turnover in creative industries in 2010, while the share in the three other countries is around $40 \%$. 
At the same time, the smallest firms in the creative industries have more employed than firms of the same size in other industries in Denmark, Norway, and Sweden. The opposite is true for Finland, where large firms in the creative industries employ less than equivalent firms in other industries. 


\section{Bilag 1. Anbefalinger til fremtidig belysning af kreative erhverv}

Dette bilag evaluerer erfaringerne med den anvendte fremgangsmåde og kommer på den baggrund med anbefalinger vedrørende:

1. Den anvendte fremgangsmåde.

2. Udbygning af den eksisterende statistiske belysning.

\section{Den anvendte fremgangsmåde}

\section{Afgrænsning af kreative erhverv}

En tværgående analyse af de kreative erhverv i Danmark, Finland, Norge og Sverige kræver en harmoniseret brancheafgrænsning, som kan genfindes i erhvervsstatistikkerne i alle fire lande. Af den årsag anvendes i denne analyse en brancheafgrænsning af de kreative erhverv, som bygger på den europæiske NACE-nomenklatur. Denne branchenomenklatur er også grundlaget for de nordiske landes brancheklassifikationer, som består af NACE brancherne med en mulig yderligere national underopdeling.

Da den valgte afgrænsning af de kreative erhverv tager udgangspunkt i en dansk afgrænsning baseret på den mest detaljerede danske brancheklassifikation, betyder anvendelsen af den harmoniserede NACE branchetilgang som udgangspunktet for afgrænsningen, at den anvendte definition medtager for mange aktiviteter. Dette gælder især inden for detail- og engroshandel.

På baggrund af erfaringerne med at anvende den harmoniserede NACE brancheklassifikation, foreslås det at gennemføre en indledende $\emptyset$ velse, hvor de nationale brancheklassifikationer i de nordiske lande screenes med henblik på at definere de kreative erhverv på et mere detaljeret og nøjagtigt brancheniveau, selvom en entydig og harmoniseret brancheafgrænsning efterfølgende ikke kan fastholdes. Det vil især være 
vigtigt for handelserhvervene, hvor den anvendte branchetilgang er for omfattende.

Omvendt kan også argumenteres, at de udvalgte kreative aktiviteter også finder sted i virksomheder, som har en anden hovedbranche end de brancher, der er medtaget i denne analyse. Efterfølgende vil en alternativ definition blive diskuteret med udgangspunkt i de ansattes uddannelse og/eller stilling i virksomhederne.

\section{Selvstændige erhvervsdrivende}

Selvstændige erhvervsdrivende uden ansatte formodes at udgøre en betydelig del af de kreative erhverv (jf. boks på side 19 med danske oplysninger). Statistiske oplysninger om disse virksomheder bør derfor fremadrettet inkluderes i en analyse af de kreative erhverv.

\section{Værditilvækst}

Værditilvækst er en nøglevariabel i forståelsen af en branches bidrag til den økonomiske vækst. I en fremtidig analyse bør inkluderingen af denne variabel for alle nordiske lande prioriteres.

\section{Udbygning af den eksisterende statistiske belysning}

Denne rapport baserer sig på særudtræk af udvalgte eksisterende erhvervsstatistikker fra statistikkontorerne i Danmark, Finland, Norge og Sverige. Den deskriptive analyse benytter derfor udelukkende oplysninger om virksomheder i de fire lande. På baggrund af erfaringerne foreslås en kommende analyse udbygget med yderligere erhvervsstatistik samt en ny tilgang med fokus på de beskæftigede personer.

\section{Udenrigshandel med varer}

De kreative erhverv fungerer som resten af erhvervslivet på et globalt marked. For at belyse de kreative erhvervs konkurrencedygtighed foreslås det, at de kreative erhvervs udenrigshandel inddrages. Dette er dog en mere ressourcekrævende udvidelse, da et sådant register først skal opbygges via matchning af erhvervsstatistikerne med udenrigshandelsstatistikkerne, som ikke i alle lande (Finland) produceres i statistikkontoret. 
De kreative erhverv indeholder både industri- og servicevirksomheder. I første omgang foreslås det, at analysen udelukkende inddrager udenrigshandel med varer, som har en betydelig bedre dækning end international handel med tjenester. Analysen vil således ikke medtage samtlige kreative erhverv, men udvalgte brancher inden for især Bøger og presse, Detail, Mode, IT (hardware og engroshandel), IT (programmering og services), Møbler og interiør samt Telekommunikationsudstyr, radio og $T V$, hvor der er en betydelig eksport af varer.

Der er to mulige tilgange, enten medtages hele eksporten fra de virksomheder, som ligger inden for de kreative erhverv, eller også udvikles en definition af kreative varer, som derefter indgår i statistikken. Sidstnævnte metode er mere arbejdskrævende i definitionsfasen, men har den fordel, at den dels er mere præcis, dels også kan medtage kreative varer, der eksporteres af virksomheder, som grundet deres brancheplacering ikke vil indgå i en kreativ branche.

\section{Erhvervsdemografi}

Oplysninger om antallet af nye virksomheder (iværksættere) og jobskabelsen i disse virksomheders første leveår vil kunne bidrage til analysen af de kreative erhvervs udvikling og bidrag til den økonomiske og beskæftigelsesmæssige vækst. Herunder kan også oplysninger om virksomheder med særligt vækstpotentiale, de såkaldte gazeller og højvækstvirksomheder, inddrages.

\section{Analyse af kreativ beskæftigelse}

Til belysning af de beskæftigede personer i kreative virksomheder foreslås at indarbejde oplysninger om stillingskategorier og uddannelser, der defineres som kreative. Hertil kan knyttes oplysninger fra flere personstatistikker som beskrevet nedenfor.

Antallet af personer, som beskæftiges i kreative stillingskategorier kan kombineres med oplysninger om løn for at belyse, hvorvidt disse stillingskategorier primært er højt- eller lavtlønnede.

Oplysninger om personer med kreative uddannelser kan anvendes til at belyse, hvor mange personer er kreativt uddannede og i hvilket omfang de arbejder inden for de kreative erhverv eller finder job i andre erhverv.

Endeligt kan de ovennævnte oplysninger anvendes til en alternativ afgrænsning af de kreative erhverv. Det kan overvejes at udarbejde en definition som tager udgangspunkt i de beskæftigedes kreative uddannelser, 
således at kun virksomheder, hvor en bestemt andel af de ansatte har en kreativ uddannelse, medtages under de kreative erhverv. Denne tilgang vil være ressourcekrævende at vedligeholde, men fordelen vil være, at samtlige virksomheder med en vis koncentration af kreativt uddannede beskæftigede medtages uanset hvilken branche, de er placeret $\mathrm{i}$. 


\section{Bilag 2. Kreative erhverv og NACE-branchekoder}

\begin{tabular}{|c|c|}
\hline NACE-branchekoder & Kreative erhverv \\
\hline 1. & Arkitektur \\
\hline 7111 & Arkitektvirksomhed \\
\hline 2. & Bøger og presse \\
\hline 1814 & Bogbinding og lignende serviceydelser \\
\hline 6391 & Pressebureauer \\
\hline 1813 & Prepress- og premedia-arbejde \\
\hline 1812 & Anden trykning \\
\hline 1811 & Trykning af dagblade \\
\hline 5814 & Udgivelse af ugeblade og magasiner \\
\hline 5813 & Udgivelse af aviser og dagblade \\
\hline 5811 & Udgivelse af bøger \\
\hline 4649 & Engroshandel med andre husholdningsartikler \\
\hline 7420 & Fotografisk virksomhed \\
\hline 3. & Design \\
\hline 7410 & Specialiseret designarbejde \\
\hline 4. & Detail \\
\hline 5914 & Biografer \\
\hline 4791 & Detailhandel fra postordre- eller Internetforretninger \\
\hline 4778 & Anden detailhandel fra specialforretninger \\
\hline 4777 & Detailhandel med ure, smykker og guld- og sølvvarer \\
\hline 4772 & Detailhandel med skotøj og lædervarer \\
\hline 4771 & Detailhandel med beklædningsartikler \\
\hline 4763 & Detailhandel med musik- og videooptagelser \\
\hline 4762 & Detailhandel med aviser og papirvarer \\
\hline 4761 & Detailhandel med bøger \\
\hline 4759 & Detailhandel med møbler og belysningsartikler samt andre husholdningsartikler \\
\hline 4753 & Detailhandel med tæpper, vægbeklædning og gulvbelægning \\
\hline 4743 & Radio- og tv-forretninger \\
\hline 4741 & Detailhandel med computere, ydre enheder og software \\
\hline 7722 & Udlejning af videobånd og videodisks \\
\hline 5. & Film og Video \\
\hline 5913 & Distribution af film, video- og tv-programmer \\
\hline 5912 & Aktiviteter, der udøves efter produktion af film, video- og tv-programmer \\
\hline 5911 & Produktion af film, video- og tv-programmer \\
\hline 6. & IT (hardware og engroshandel) \\
\hline 5821 & Udgivelse af computerspil \\
\hline 2620 & Fremstilling af computere og ydre enheder \\
\hline 4651 & Engroshandel med computere, ydre enheder og software \\
\hline 7. & IT (programmering og services) \\
\hline 6202 & Konsulentbistand vedrørende informationsteknologi \\
\hline 6201 & Computerprogrammering \\
\hline 5829 & Anden udgivelse af software \\
\hline
\end{tabular}




\begin{tabular}{|c|c|}
\hline NACE-branchekoder & Kreative erhverv \\
\hline 8. & Kunst og kunsthåndværk \\
\hline 9003 & Kunstnerisk skaben \\
\hline 9004 & Drift af teater- og koncertsale, kulturhuse mv. \\
\hline 9002 & Hjælpeaktiviteter i forbindelse med scenekunst \\
\hline 9001 & Scenekunst \\
\hline 9. & Mode \\
\hline 1419 & Fremstilling af andre beklædningsartikler samt tilbehør \\
\hline 1411 & Fremstilling af beklædningsartikler af læder \\
\hline 4642 & Engroshandel med beklædning og fodtøj \\
\hline 1414 & Fremstilling af underbeklædning \\
\hline 3213 & Fremstilling af bijouteri og lignende varer \\
\hline 1520 & Fremstilling af fodtøj \\
\hline 1420 & Fremstilling af varer af pelsskind \\
\hline 1413 & Fremstilling af anden yderbeklædning \\
\hline 1512 & Fremstilling af tasker, kufferter, sadelmagervarer mv. \\
\hline 2652 & Fremstilling af ure \\
\hline 3212 & Fremstilling af smykker i ædle metaller og relaterede produkter \\
\hline 1412 & Fremstilling af arbejdsbeklædning \\
\hline 1439 & Fremstilling af andre strikkede og hæklede beklædningsartikler \\
\hline 4616 & Agenturhandel med tekstiler, beklædning, pelsværk, fodtøj og lædervarer \\
\hline 4648 & Engroshandel med ure, smykker og guld- og sølvvarer \\
\hline 10. & Musik \\
\hline 3220 & Fremstilling af musikinstrumenter \\
\hline 5920 & Indspilning af lydoptagelser og udgivelse af musik \\
\hline 1820 & Reproduktion af indspillede medier \\
\hline 11. & Møbler og interiør \\
\hline 4644 & Engroshandel med porcelæns- og glasvarer og rengøringsmidler \\
\hline 3109 & Fremstilling af andre møbler \\
\hline 1393 & Fremstilling af tæpper \\
\hline 4647 & Engroshandel med møbler, tæpper og belysningsartikler \\
\hline 4615 & Agenturhandel med møbler, husholdningsartikler og isenkram \\
\hline 2740 & Fremstilling af elektriske belysningsartikler \\
\hline 1392 & Fremstilling af færdige tekstilvarer undtagen beklædningsartikler \\
\hline 2341 & Fremstilling af keramiske husholdningsartikler og pyntegenstande \\
\hline 12. & Reklame \\
\hline 7311 & Reklamebureauer \\
\hline 13. & Telekommunikationsudstyr, radio og TV \\
\hline 6020 & Tv-virksomhed \\
\hline 6010 & Radiovirksomhed \\
\hline 2630 & Fremstilling af kommunikationsudstyr \\
\hline 4643 & Engroshandel med elektriske husholdningsartikler \\
\hline
\end{tabular}




\section{Bilag 3. Detaljerede figurer}

Figur 11. Omsætning pr. årsværk i kreative og øvrige erhverv. 2010

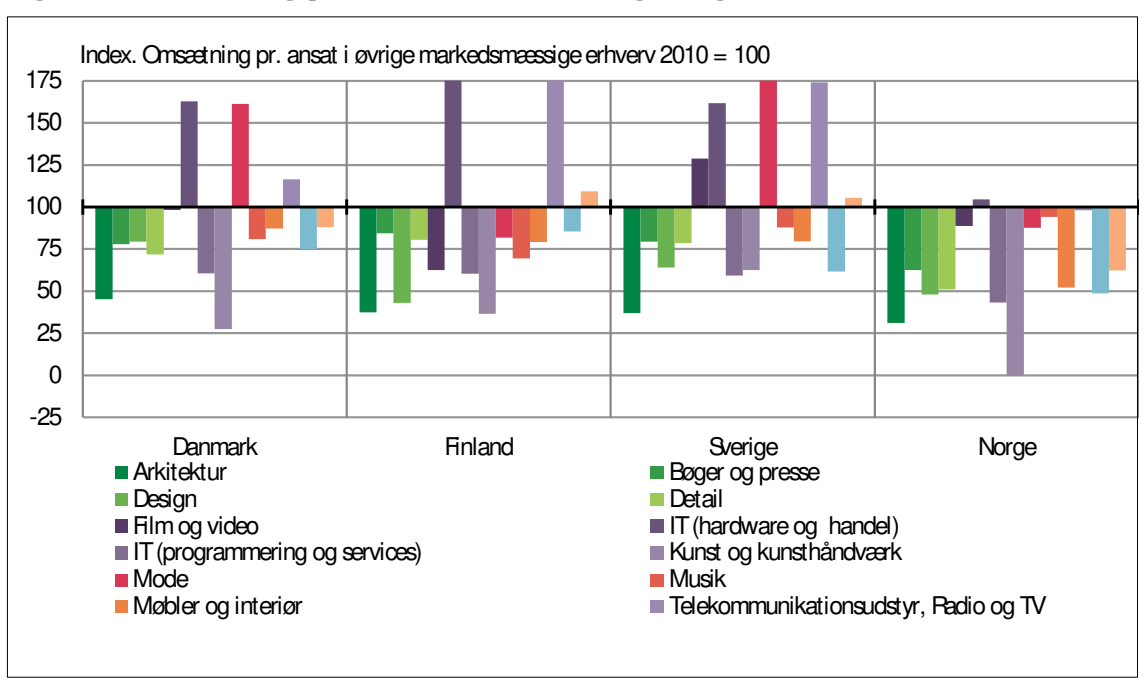

Figur 13. Værditilvækst pr. ansat i kreative og øvrige erhverv. 2010

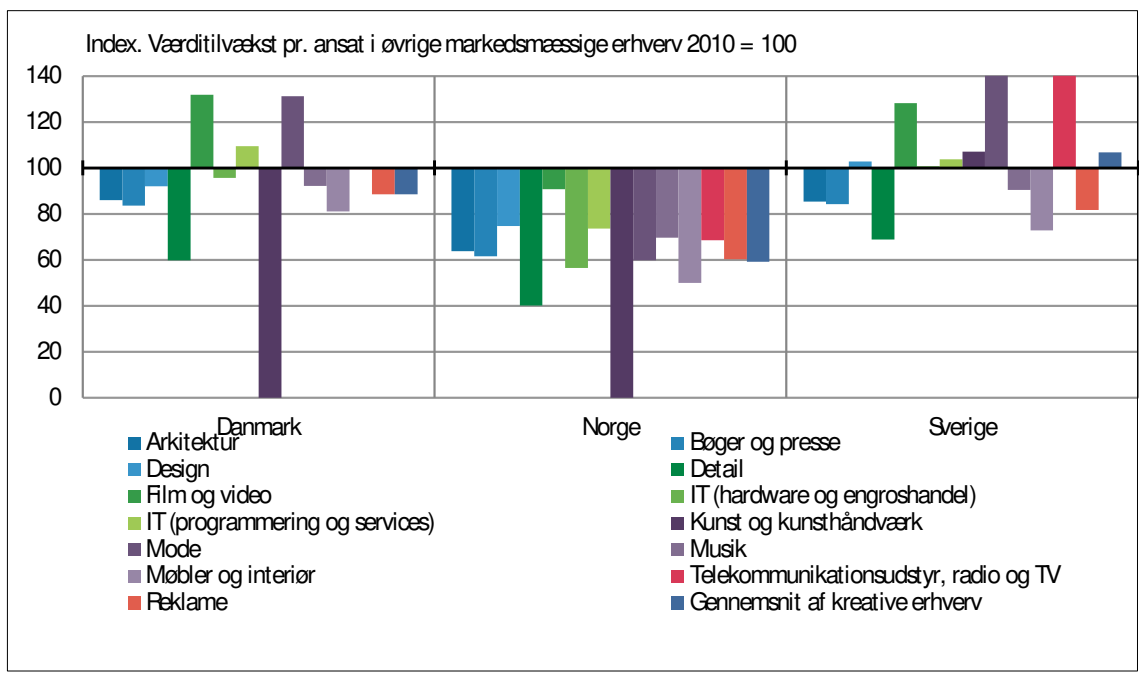

Oplysninger om værditilvækst findes ikke for Finland. 
Andel af værditilvækst i kreative og øvrige erhverv fordelt på virksomhedsstørrelse. 2007 og 2010

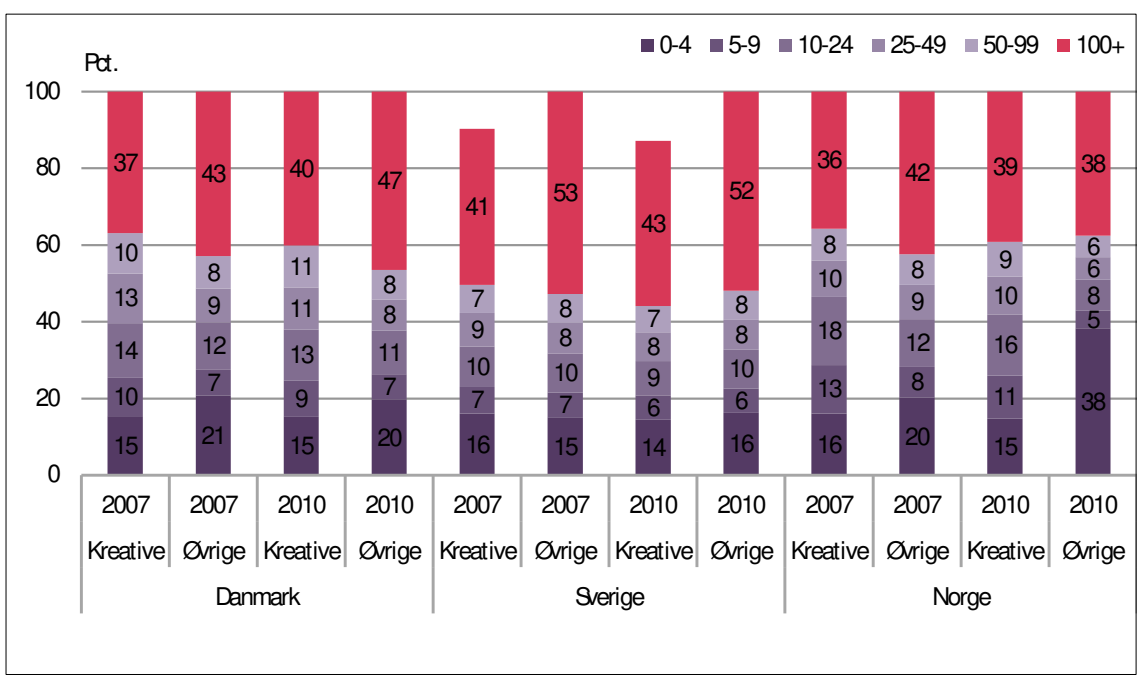

Andel af værditilvækst pr. virksomhed i kreative og øvrige erhverv fordelt på virksomhedsstørrelse. 2010

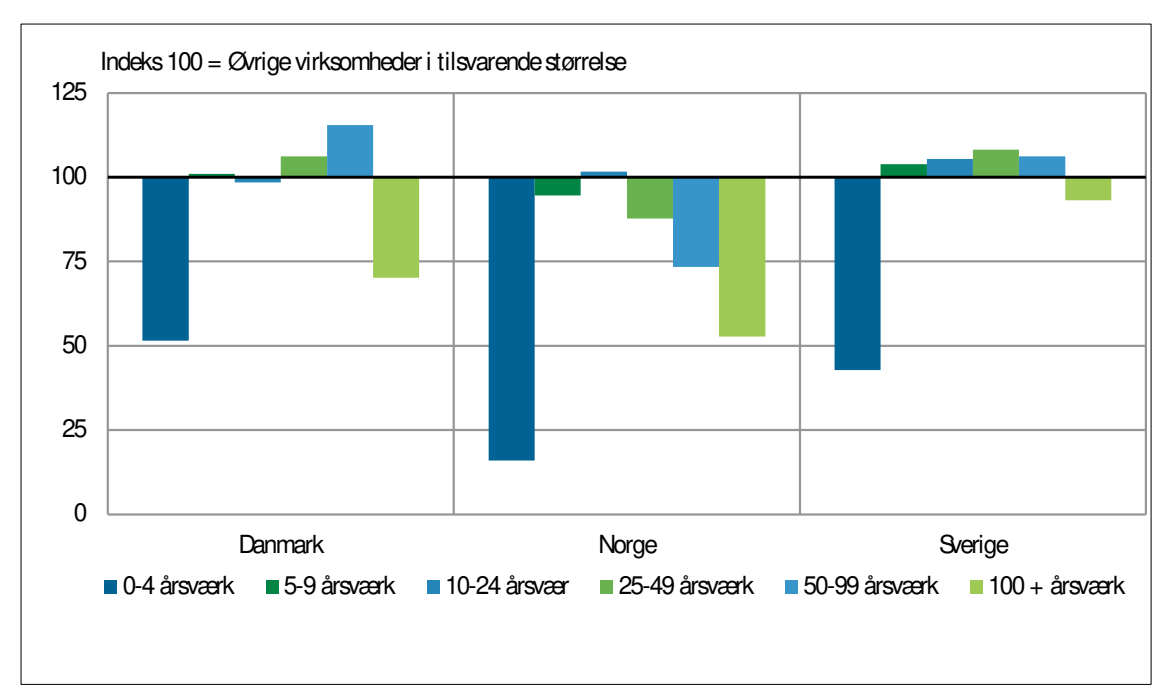




\section{norden}

Nordisk Ministerråd

Ved Stranden 18

DK-1061 København K

www.norden.org

\section{Kreative erhverv i Norden}

Kreative erhverv har de seneste år udgjort en stadig større andel af Nordens økonomi. Formålet med rapporten er at kortlægge de kreative erhvervs betydning for økonomierne i Danmark, Finland, Norge og Sverige, og derigennem skabe et opdateret videngrundlag for en øget udnyttelse af erhvervsmæssigt potentiale i Nordens kreative erhverv. Analysen, udført af Danmarks Statistik for KreaNord i 2012, belyser landenes kreative erhverv og baserer sig på erhvervsstatistiske oplysninger fra eksisterende statistikregistre i Danmark, Finland, Norge og Sverige.

Genudgivet i 2015 i forbindelse med afviklingen af KreaNord, Nordisk Ministerråds initiativ om kulturelle og kreative erhverv (2008-2015).

TemaNord 2015:554

ISBN 978-92-893-4255-1 (PRINT)

ISBN 978-92-893-4257-5 (PDF)

ISBN 978-92-893-4256-8 (EPUB)

ISSN 0908-6692 